\title{
Ibn Taymiyya, al-Siyāsa al-Shar'iyya, and the Early Modern Ottomans
}

\author{
Derin Terzioğlu
}

The Hanbali scholar Taqī l-Dīn Ibn Taymiyya (d. 728/1328) would not be among the first names to come to mind when one thinks of the pre-Ottoman Muslim scholars whose oeuvres were influential in the making of Ottoman Sunnism. There are many reasons for this. The Hanbali legal school (madhhab) to which Ibn Taymiyya belonged was not only the smallest of the four "Sunni" legal schools but also arguably the furthest removed from the Hanafi legal school, to which the vast majority of the Muslims of the lands of Rum (Anatolia and the Balkans) belonged and which the Ottoman administration promoted as the "default madhhab" throughout its provinces. ${ }^{1}$ Besides, Ibn Taymiyya was, both in his own time and in later periods, a sharply divisive figure, who had provoked controversy even among his fellow Hanbalis for deviating from the madhhab consensus on such issues as divorce oaths. ${ }^{2}$ Outside Hanbali circles, he was also widely condemned for his anthropomorphic interpretation of God's attributes and for his attacks against the visitations of the tombs of prophets and saints. To many Rumi Muslims, whose understanding of Islam was strongly colored by Sufism, Ibn Taymiyya's rejection of a wide variety of Sufi beliefs and practices and his anathematization of the Andalusian mystic Muhyī l-Dīn Ibn 'Arabī (d. 638/1240) as "Shaykh Akfar" (the most blasphemous master) would have seemed deeply objectionable as well. ${ }^{3}$

1 For a view of the Hanafi legal school as the "default" or "semidefault" legal school in Ottoman Egypt, see Ibrahim, Pragmatism, esp. 139, 149-161; for a discussion of the same as the "state madhhab" in the Ottoman lands, see Burak, The second formation and Peters, What does it mean.

2 Bori, Ibn Taymiyya wa-jamāáatuhu esp. 23-36; al-Matroudi, The Hanbalī school; Melchert, The relation of Ibn Taymiyya 146-161.

3 For a study that has argued for the marginality of Ibn Taymiyya among non-Hanbali scholars of the Ottoman period on the grounds summarized above, see el-Rouayheb, From Ibn Hajar al-Haytamī; for a study that has qualified this picture with new evidence for Ottoman scholarly awareness of Ibn Taymiyya, see Bori, Ibn Taymiyya (14th to 17th century) 112-120. 
Notwithstanding these differences between the kind of Sunni Islam that Ibn Taymiyya upheld and the kind of Sunni Islam to which the vast majority of the Ottoman learned elites adhered, however, Ibn Taymiyya was not entirely unappreciated in the Ottoman lands. In fact, since the 1980s, scholars such as Ahmet Yaşar Ocak and, more recently, Yahya Michot and Mustapha Sheikh have argued that there was even an Ottoman "school of Ibn Taymiyya," whose adherents included the famous tenth/sixteenth century Hanafi jurist Birgili/Birgivī Mehmed Efendi (d. 981/1573) and his eleventh/seventeenth-century followers, known in the secondary literature and in some Ottoman sources as the Kadızadelis. Some of these scholars have further placed the Kadizadelis in a specific genealogy of "Islamic revivalism," or "Salafi Islam," extending from Ibn Taymiyya to the Wahhabis. ${ }^{4}$ However, other scholars have (in my opinion, rightly) objected to this genealogy on grounds that both Birgivi and the Kadizadelis were firmly rooted in the Hanafi-Maturidi tradition and that the evidence for their use of Taymiyyan ideas is both questionable and limited. ${ }^{5}$

This paper argues that the most concrete evidence we have at hand of Taymiyyan influences among the Ottoman men of letters in the early modern era points to a rather different, much more imperial, context for the reception of Taymiyyan ideas. The work of Ibn Taymiyya that most resonated with the Ottoman learned elites from the mid-tenth/sixteenth century onward was a juristic treatise on governance titled al-Siyāsa al-shar'iyya fı̀ ișlāh al-rā̄ì wa-lraiyya (Shari governance for the betterment of the ruler and the ruled). Significantly, the Ottoman men of letters who took an interest in this text did not necessarily represent the "more stringent" or "more traditionalist" among their peers. Rather, what attracted them to this treatise was its authorization of a strong state for a stable society founded on shar $i$ principles, for this was also how they saw, or at least wished to see, their state. Just as importantly, the notion of siyassa shariyya (governance based on the principles of Islamic law) offered a useful conceptual framework to reconcile the Ottoman dynastic law known as kānūn with the universalizing norms of the sharia. Of course,

4 Ocak, XVII. Yüzyılda 208-225; Şimşek, Les controverses; Öztürk, Islamic orthodoxy; Çavuşoğlu, The Kāḍizādeli, esp. 39-47, 93-100; Lekesiz, xvI. Yüzyl; Michot, Introduction 1-4, 18-19, 37-39; Sheikh, Taymiyyan influences 1-20; Sheikh, Ottoman puritanism, 93; Sheikh, Taymiyyan tașawwuf; Evstatiev, The Qāḍizādeli movement and the spread 3-34; Evstatiev, The Qāḍizādeli movement and the revival 213-243; Currie, Kadızadeli 1-25. Note that Michot and Sheikh reject the "Salafi" label as anachronistic and inappropriate for both Ibn Taymiyya and the Kadizadelis.

5 Radtke, Birgiwīs Ṭarīa Muḥammadiyya, 159-174; el-Rouayheb, From Ibn Ḥajar al-Haytamī 303-304; Martı, Birgivî 65-68; Ivanyi, Virtue, esp. 76-82. 
Ibn Taymiyya had developed his thoughts on siyāsa shariyya in the significantly different legal and administrative context of the Mamluk sultanate, and in transplanting his teachings to their own context, the Ottoman writers had to rethink aspects of those teachings in view of their own legal and administrative practices.

In this paper, I examine the Ottoman Rumi scholars' engagement with Ibn Taymiyya's al-Siyāsa al-shar'iyya in the context of the transformation of Ottoman imperial ideology under the impact of both multifaceted changes in the political arena and growing Sunni confessionalism. While Ottoman Sunnism had multiple sources of inspiration, this paper assesses in particular the impact of a certain corpus of juristic literature that came out of the Mamluk lands on some of the later Ottoman scholarly discussions and trends (a concern shared with the contributions by Helen Pfeifer, Nabil Al-Tikriti, and Guy Burak in this volume). With this aim in mind, the next two sections shall introduce Ibn Taymiyya's al-Siyāsa al-shar'iyya and the broader corpus of siyāsa shar'iyya texts as they took shape in the Mamluk context and discuss how and why this text, along with some other texts in this corpus, attracted the attention of Rumi scholars first around the mid-tenth/sixteenth century. Then, in the third and fourth sections, I shall examine how two rather different Rumi scholars, the mufti and mudarris Dede Cöngī (d. 975/1567) and the belle-lettrist and kadi 'Āşı Çelebi (d. 979/1572) engaged with the ideas expressed in this corpus. These more textually grounded sections of the paper shall highlight not just what the Ottoman scholars took from the earlier scholarly discussions but also what they brought to them that was new (an emphasis shared with the papers by Tijana Krstić, Nir Shafir, and Evren Sünnetçioğlu in this volume). At the same time, this discussion will bring out the complexity and contradictions in the Ottoman reflections on their own religiopolitical order and emphasize the interplay of religious ideology and political expediency in this regard. This theme is continued in the fifth and last section, which examines the afterlives of the works of Cöngī and 'Āşı Çelebi during the eleventh/seventeenth century, when the aforementioned Kadızadeli preachers became ascendant in the Ottoman capital. We shall see that notwithstanding the intensification of intra-Sunni debates and the occasional use of Ibn Taymiyya's name by Sufis to cast aspersion on their critics, both Ibn Taymiyya's al-Siyāsa al-shar'iyya and its Ottoman offshoots appealed to the Kadızadeli and non-Kadızadeli alike and found a more enthusiastic audience than before, during the eleventh/seventeenth century. I will argue that this was due less to a "Salafi" (or proto-Salafi) turn among the Hanafi scholars of Rum and more to the fact that the notion of siyassa shariyya answered well the practical and ideological needs of the Ottoman ruling elites in a time of social and political transformation. 


\section{Ibn Taymiyya and the Development of the Idea of Siyāsa Shariyya under the Mamluk Sultanate}

Just as the Ottomans were one of the most successful states to be formed by a Muslim dynasty in the aftermath of the Mongol invasion, Ibn Taymiyya was one of the most novel Muslim thinkers to reflect upon and respond to the realities of the post-Mongol era. He was born in 661/1263 to a scholarly family in Harran, a town that had to surrender to Mongol rule a few years previously. When Ibn Taymiyya was six years old, his family relocated to Damascus, where they would spend the rest of their lives under the rule of the newly formed sultanate of the Mamluks. Even though the Mamluks successfully checked the Mongol advance, the early decades of their rule were also marked by political instability and infighting, and a sense of crisis among the civilian elites. It was in this environment that Ibn Taymiyya developed a close, if also fraught, relationship with the Mamluk authorities. On the one hand, he ran to their aide by preaching jihad against the sultanate's Mongol, Christian, and Shi'ite enemies, and by providing the Mamluk rulers with religious and political counsel. On the other hand, he also angered the Mamluk officials by entering into heated polemics with fellow scholars and was periodically imprisoned. ${ }^{6}$

It was mainly Ibn Taymiyya's theological and juridical views that landed him in trouble with the Mamluk authorities. By contrast, no such controversy surrounded his political tract, al-Siyāsa al-shariyya fì ișlāh al-rāì wa-l-raciyya, written between $711 / 1311$ and $714 / 1315 .{ }^{7}$ This treatise is widely accepted to be a milestone in the history of Islamic political thought even though the nature of its significance has been construed differently by different scholars. In 1939, Henri Laoust famously argued that with this treatise Ibn Taymiyya had replaced the classical juristic discourse, centered on the institution of the caliphate, with another, centered on the implementation of the sharia. ${ }^{8}$ Recently, Mona Hassan has successfully challenged this view by showing that Ibn Taymiyya continued to refer to the caliphate as both an ideal form of government and a historical institution in various writings. ${ }^{9}$ Ovamir Anjum, on the other hand, has maintained that Ibn Taymiyya did indeed break with classical juristic thought but by rejecting the formalism and quietism of the classical jurists and by advocating a return to the unified religiopolitical authority and political activism of

6 Laoust, Ibn Taymiyya 951-955.

7 Ibid. 952 .

8 Laoust, Essai $278-315$.

9 Hassan, Modern interpretations 338-366; Hassan, Longing 111-115. 
the Muslim polity in its earliest years. ${ }^{10}$ Whereas Anjum and Caterina Bori have read Ibn Taymiyya as reconceptualizing "Islamic politics" as a more inclusive realm that was of relevance to rulers and ruled alike, Abdessamed Belhaj has seen him instead as a social conservative whose fear of instability and disorder led him to support an expanded role for the state. ${ }^{11}$

Arguably, there are insights to be gained from all these approaches to Ibn Taymiyya's al-Siyāsa al-shariyya. Even if the Hanbali scholar did not proclaim the caliphate to be moribund in his time, he still de-emphasizes it in this particular treatise, using such terms as "caliph" and "imam" exceedingly rarely and omitting altogether any references to the juristic debates about the conditions for accession to the office of the caliph. The sole criterion that Ibn Taymiyya articulates for legitimate rulership is that rulers service the Muslim community by upholding the sharia and protecting public order. He defines "the exercise of authority for the benefit of the people" (wilāyata amr al-nās) as "one of the greatest religious duties," and he identifies princes and jurists as the two primary groups of people entrusted with this responsibility. ${ }^{12} \mathrm{Ibn}$ Taymiyya's authoritarian and collectivist tendencies are especially evident in his conceptualization of siyassa and its relationship to the sharia. A term with a range of meanings, siya $\bar{s} a$ connoted before the modern era: 1) statecraft and the management of the subject people (raiyya);2) "the discretionary authority of the ruler and his officials, one which they exercise outside the framework of the Shari'a"; and by extension, 3) punishment, particularly punishment that exceeds the hadd punishments prescribed by Islamic law. ${ }^{13}$ While some jurists had viewed siyassa in the second and third senses with a great deal of misgiving and even opposition, Ibn Taymiyya saw a meaningful role for the legal authority of the ruler as long as it did not violate the precepts of the sharia but rather helped to reinforce them and to maintain and protect public order. Because he regarded the exercise of authority and coercion to be indispensable for fulfilling the Quranic injunction to "command the right and forbid the wrong" (amr bi-l-ma'rüf wa-nahy 'an al-munkar), he particularly supported measures that enhanced the coercive power of the state and protected the collective interests

\footnotetext{
10 Anjum, Politics.

11 Ibid.; Belhaj, Law and order 401, 409, 420-421; Bori, One or two versions 6-7.

12 Ibn Taymiyya, al-Siyāsa 163; for the English translation, see Ibn Taimiyya on public 187. Henceforth, references will be given to both versions, separated by a slash. Note that there is also a longer version of this epistle, which remains in manuscript form, but it was far less widely circulated and was not the one to be translated into Turkish, so it will not be referenced here. For a discussion of the differences between the two versions, see Bori, One or two versions.

13 Bosworth, Netton and Vogel, Siyāsa 693-696; see also Belhaj, Law and order 401-402.
} 
of the Muslim community. ${ }^{14}$ It was for similar reasons that he condoned the use of judicial torture and circumstantial evidence in the conviction of suspected criminals, something that had been opposed by the majority of earlier jurists. ${ }^{15}$

It must be pointed out that the notion of siyassa shar'iyya was not solely the brainchild of Ibn Taymiyya. Several other Shafi'i, Maliki, and Hanbali jurists had also discussed the concept of siyassa from the viewpoint of "shar i normativity" before him, but the corpus truly developed in the late seventh/thirteenth and early eighth/fourteenth centuries, when scholars such as Shihāb al-Dīn al-Qarāfí (d. 684/1285) as well as Ibn Taymiyya and his student Ibn Qayyim al-Jawziyya (d. $751 / 1350$ ) gave it its distinctive form. ${ }^{16}$ Significantly, all these jurists lived in the Mamluk sultanate, where there was a high degree of "symbiosis" between the ulama and military officials, and where norms of figh and practical considerations of governance were closely conjoined in the actual practice of law. ${ }^{17}$ A novel feature of the Mamluk legal system was that they appointed to each major town four chief judges (qā of the four Sunni legal schools; this was a set up that allowed the legal mechanism to be both predictable and flexible and enabled the political authorities to obtain the results that they considered to be the most conducive to social order. It was also in the Mamluk period that the mazālim or siyāsa courts proliferated and expanded their jurisdiction to encompass such matters as marriage, even though the most radical developments in this regard would come in the second half of the eighth/fourteenth and, especially, the ninth/fifteenth centuries. ${ }^{18}$ Even if the early eighth/fourteenth-century proponents of siyāsa shariyya could not have anticipated these later developments (much less condoned them), they can be said to have unwittingly opened the way for them by translating into political discourse what must have been a wider societal demand for law and order.

However, not all Mamluk-era jurists were as positive about the expansion of administrative justice; nor were they all convinced of its compatibility with shar $i$ norms. In the ninth/fifteenth century, scholars critical of the excesses

14 For a discussion of Ibn Taymiyya's views on amr bi-l-ma'rüf and its connection to his political thought, see Cook, Commanding right 151-157.

15 Johansen, Signs as evidence $168-193$.

16 On the earlier history of the corpus, see Massud, The doctrine of siyāsa; Belhaj, Law and order 402-403. Even though siyāsa shar'iyya as a juridical concept was given full force by Ibn Taymiyya, Belhaj points out that the concept was already being used by Muhyī l-Dīn Ibn 'Arabī a century earlier.

17 Lev, Symbiotic relations; Stilt, Islamic law.

18 Rapoport, Royal justice 71-102; Rapoport, Legal diversity 210-228; see also Nielsen, Secular justice. 
of the Mamluk siyassa tradition sought to discredit it by associating it with the yasa of Chinggis Khan. Some, like Maqrizī (d. 845/1442) and Ibn Taghrībirdī (d. 874/1470), even proposed that the word siyāsa comes from the Persian word se, meaning "three," and the Mongol word yasa, because Chinggis Khan had divided his realms between his three sons, turning his yasa, in effect, into "se yāsa," or three yasas prevalent in three different realms. ${ }^{19}$ Tellingly, however, even these more critical commentators found it difficult to reject the siyāsa tradition completely and often distinguished between "just" and "unjust" siyāsa, following a formulation first articulated by Ibn Qayyim al-Jawziyya and repeated in many other works afterwards. ${ }^{20}$

\section{2 \\ Transplanting the Notion of Siyāsa Shar iyya to the Ottoman Context}

Siyāsa had also been a part of the Ottoman legal and administrative vocabulary from at least the ninth/fifteenth century onward. However, as Guy Burak has noted, the "Ottoman siyaset" did not have the same meaning as the "Mamluk siyāsa," since the Ottomans had been, well into the tenth/sixteenth century, much more in tune with the juristic and administrative traditions of the "postMongol" East (Iran and Central Asia) than with those of Egypt and Syria under the Mamluks. In the Ottoman kānūnnāmes, or lawbooks, the term "siyāsa" was used in the narrower sense of administrative punishment and drew its power not just from the reigning sultan, as in the Mamluk context, but also from the cumulative legal tradition of the Ottoman dynasty, as in the case of the Chinggisid yasa $^{21}$

The "Ottoman siyaset" did, nevertheless, have a broader meaning, that of "governance," when it was used in the Ottoman ethics (ahläk) literature, which was modeled on the Persian "ethico-philosophical" literature. ${ }^{22}$ This broader definition of siyāset also informed the famous discursus of Țursun Beg (d. after $896 / 1491)$ on law and governance in the preamble to his history of Mehmed II (r. 848-850/1444-1446, 855-886/1451-1481). There, citing the authority of "philosophical works" (kütüb-i hikemiyye), the madrasa-trained bureaucrat distinguishes between two types of siyasset, both of which can potentially lead to

19 Rapoport, Royal justice 95-96. For a debunking of the claim of Chinggisid influence over Mamluk siyāsa, see Ayalon, The great yāsa 107-156.

20 Rapoport, Royal justice 95-96.

21 Burak, Between the kānūn esp. 20-23.

22 Sariyannis, A history 433-434. 
an ordered state of affairs in human society: "that which the philosophers (ehli hikmet) call divine governance (siyâset-i İlâhî), and which the people of sharia call sharia," and that which is issued by rulers using their reason, like the laws of Chinggis Khan, "which is called royal governance and law (siyâset-i sultânî ve yasağ-ı padişâhî) and according to our custom (örf), customary law (örf)."23 It is noteworthy that Țursun Beg considered both the sharia and ruler's law, including the laws of Chinggis Khan, to be legitimate, even as he emphasized the superiority of the first over the second. Interestingly, Tursun does not mention the Ottoman kānūn in this passage, even though some of his readers would probably have also thought of it in the same connection, judging by the fact that kānūn and yasa (or yasağ) were sometimes used interchangeably in the Ottoman sources of the period. ${ }^{24}$

Yet the fact that the Ottoman legal tradition had more in common with that in other post-Mongol polities to their east does not mean that Rumi scholars were completely unaware of the Mamluk legal and administrative traditions or of the Mamluk siyassa literature before the tenth/sixteenth century. An important conduit of ideas in this regard would have been the students and scholars who traveled between the two realms already during the ninth/fifteenth century. ${ }^{25}$ One of the early scholars who might have been instrumental in bringing to the lands of Rum knowledge of the juristic literature of Mamluk Syria was 'Alā l-dīn 'Alī Tarābulusì (d. after 849/1445), who was a kadi of Jerusalem and one of the earliest Hanafi scholars to draw on the concept of siyassa shariyya in his manual for kadis entitled Muin al-hukkām. Tarābulusī traveled to the then-Ottoman capital Edirne and presented some works to Murād II (r. 824848/1421-1444, 848-855/1446-1451), but not, it seems, Mu'in al-hukkām. The text, which would be much cited by later Ottoman writers, is notable by its absence from the Ottoman palace library inventory of $908-909 / 1502-1504 .{ }^{26}$ Another scholar whose works dealt with issues of siyassa and traversed the Mamluk and Ottoman realms was Muhyī l-Din Kāfiyeci (d. 879/1474). Interestingly, Kāfiyeci was Rumi in origin. Born in Bergama in western Anatolia, he had acquired his education during his travels in Anatolia, Iran, and Syria before

23 Tursun Bey, Târîh-i Ebü'l-Feth 10-12.

24 For examples of the interchangeable use of kānūn and yasa in the Rumi/Ottoman context, see Burak, The second formation 595-597.

25 For preliminary findings on scholarly mobility in the Ottoman realms, see Ökten, Scholarly mobility; Burak, The second formation, ch. 4; Karamustafa, Saraydan 55-56; Taşkömür, Books 395-396. On the roles played by scholars in Mamluk-Ottoman diplomatic relations, see Muslu, The Ottomans esp. $25^{-28}$.

26 Taşkömür, Books 397; on Ṭarābulusī’s life and career, see Karaman, Trablusî. Muiñ alhukkām will be discussed further below as one of the primary sources of Cöngì's epistle. 
settling in Cairo, where he gained renown as a versatile scholar and authored, among other works, two epistles, entitled Sayf al-mulūk (The sword of rulers) and Sayf al-quḍāt (The sword of kadis). Even though Kāfiyeci never returned to the lands of Rum, he maintained a connection with the Ottoman court, or at least with the grand vizier Mahmūd Pasha (d. 878/1474), and dedicated to him several of his works, including Sayf al-mulük. ${ }^{27}$

Despite these early points of contact, nevertheless, it was not until the tenth/sixteenth century that the Hanafi scholars who were based in Rum began to take a greater interest in the Mamluk siyāsa literature in general and in Ibn Taymiyya's al-Siyassa al-shariyya in particular. This interest developed in the wake of three major developments. First, the rise of the Safavids in 9o6/1501 as a rival Shi'itizing dynasty and the flaring up of a full-fledged ideological and military conflict between the Ottomans and the Safavids a decade later infused Ottoman religious and political culture with an unprecedented degree of Sunni confessionalism. It also impressed upon the imperial elites the need to eradicate or at least limit the "heterodox" forms of Islam in the Ottoman lands and to address and correct the divergences between the established Ottoman practices and the universalizing norms of the sharia. ${ }^{28}$ In their effort to formulate a stronger response to the "heresies" of their time, the overwhelmingly Hanafi-Maturidi scholars of Rum also began to look beyond their own legal and theological traditions and to selectively utilize the arguments of some Shafi'i, Maliki, and, to a lesser extent, Hanbali jurists alongside those of the Hanafi authorities. ${ }^{29}$

$27 \quad$ For a study of the life and scholarly contributions of Kāfiyeci and the Arabic edition and Turkish translation of his two aforementioned works, see el-Kâfiyeci, Seyfüll-mülûk; for a discussion of these works, see also Köksal, Fikıh ve siyaset 159-168. Sayf al-mulūk must have entered the Ottoman palace library after 9o8-909/1502-1504, since the text does not appear in the inventory made by the librarian Hayre'd-dīn Hiżır 'Ațūî then. On Kăāiyeci's relation to Mahmūd Pasha and the works he devoted to the latter, which were also transferred to the palace library, see Taşkömür, Books 398. In the mid-tenth/sixteenth century, Kăfiyeci's ties with the Ottoman world were deemed sufficient for Țaşköprüzāde to include him in his biographical dictionary of the scholars of Rum; see Taşköprülüzâde, eş-Şakâik 118-122.

28 On the impact of the rise of the Safavids on Ottoman imperial ideology and on Ottoman religious and political culture more generally, see Sohrweide, Der Sieg; Eberhard, Osmanische Polemik; Üstün, Heresy; Fleischer, The Lawgiver; Dressler, Inventing; Al-Tikriti, Kalam; Krstić, Illuminated; Krstić, Contested conversions; Krstić, From shahāda; Krstić, State and religion; Terzioğlu, Where 'ilm-i hạal meets; Terzioğlu, How to conceptualize; Burak, Faith; Şahin, Empire 205-213; Çıpa, The making; Atçıl, The Safavid threat.

29 It seems that the Ottoman şeyhü'l-islāms Kemālpaşazāde and Ebū's-su'ūd drew especially on Maliki and Shafi'i works and only secondarily on Hanbali ones in this context. On the 
A second development that was perhaps even more consequential for the beginning of the Ottoman engagement with the siyassa al-shar'iyya corpus was the incorporation of Egypt and Syria into the Ottoman realms following the Ottoman victories against the Mamluks in 922-923/1516-1517. In the aftermath of the conquest, prominent Rumi scholars were appointed as kadis, mudarrises, and surveyors to such cities as Aleppo, Damascus, and Cairo, where they fraternized, competed, and sometimes clashed with local scholars of different madhhab affiliations. This experience also exposed the Rumi scholars to the debates among the Syrian and Egyptian scholars about the Ottoman kānūn, or as the latter scholars often preferred to call it, by way of association with the Chinggisid yasa, "the Ottoman yasağ." ${ }^{30}$ Evidence of Rumi familiarity with the antiyasa/yasağ discourse of some Egyptian and Syrian scholars crops up in a variety of texts from this period. For instance, the eminent scholar Kemālpaşazāde, also known as Ibn Kemāl (d. 940/1534), who, as military justice (ḳậ̂̄iasker) of Anatolia, had accompanied the Ottoman sultan Selīm I during his Egyptian campaign and taken part in Egypt's first land survey, recycled the Mamluk-era pseudoetymology that derived the word siyāsa from the "three yasas" of Chinggis Khan's three sons. ${ }^{31}$ Since Kemālpaşazāde mentioned this etymology in a treatise on the "Arabicization of foreign words" rather than in a juristic treatise, it is not clear what greater significance, if any, he assigned to this supposed etymological connection between the yasa and siyāsa, but some other Rumi scholars who had spent time in the former Mamluk lands differentiated much more sharply between divinely originated and human-made laws and came out clearly against the yasa. Such was, for instance, the case with Kinalızāde 'Alī Efendi (d. 979/1572), who condemned the Chinggisid yasa unequivocally in his Ahlāk-ı Alà's, which he wrote circa 972/1564-1565 while serving as kadi of Dam-

verifiable instances of borrowing, see Üstün, Heresy 240-268; Al-Tikriti, Kalam; for inconclusive evidence about the use of a work by Ibn Taymiyya by the Ottoman scholar and lettrist 'Abdu'r-rahmān al Bisțāmī (d. 858/1454), see Gril, Ésotérisme 192.

30 On the scholarly exchanges between Rumi and Egyptian and Syrian scholars during the tenth/sixteenth century, see Winter, Society and religion 185-188; Meshal, Antagonistic sharīas; Burak, Faith, law and empire; Burak, The second formation esp. chs. 2-4; Pfeifer, Encounter; see also Pfeifer's essay in this volume. On the anti-yasa/yasağ discourse of the Syrian and Egyptian scholars in this period, see Burak, Between the kānūn 15-20; for a more nuanced (albeit still critical) assessment of the Ottoman legal system by the Egyptian scholar Zayn al-Dīn Ibn Nujaym (d. 970/1563), see Ayoub, Law, empire, and the sultan 31-63.

31 Interestingly, a later copyist found it appropriate to excerpt this passage right before a copy of Cöngī's Risāla fì l-siyāsa al-shar'iyya. The excerpt is titled, "Siyāsa from the Risāla alTa'rīb by Ibn Kemālpaşa," in ms Süleymaniye Kütüphanesi (hereafter sk), Ms Esad Efendi 924, 166a. 
ascus. Baki Tezcan has argued that Kınalızāde's strong condemnation of the yas $a$ also bespoke his ambivalence about the Ottoman kānūn, which, however, is not explicitly mentioned in this text. ${ }^{32}$ Another contemporary Rumi writer who had taken part in the Ottoman conquest of Egypt and who had also spent some time in that province and, subsequently, was more explicit in his criticism of, if not kānūn, then of those who invested binding power in it. In his book of advice, written sometime between $962 / 1555$ and $974 / 1566$, and addressed to the grand vizier, the anonymous author of the Kitäbu Meșālihüll-Müsliminn repeatedly emphasizes that kānūns are made by administrators to meet the needs of their time; they are not "from the time of the Prophet, hence it cannot be a sin (günāh) to change them." Clearly, however, the same writer was not oblivious to the reputation of the Ottoman laws; hence, he urged the grand vizier not only to issue new laws (yasak, yasa $\breve{g}$ ) but also to do his utmost to enforce them "so that people will not say that the Ottoman yasağ lasts until the forenoon" (Osmanlunun yasağı hod kuşluğa değindir dimeyeler). ${ }^{33}$

Third and last, the growing anxiety among the scholars of Rum about the compatibility of the Ottoman kānūn with the sharia during the first half of the tenth/sixteenth century prompted efforts on the part of the leading Ottoman jurists to try to address and reduce these points of tension. Some high-ranking jurists, like Çivizāde Muhȳìd-dīn Mehmed (d. 954/1547), tried to accomplish this by undertaking a sustained critique of those Ottoman institutions and practices that they deemed problematic, such as cash waqfs, but met stiff resistance on the part of the Ottoman imperial establishment in this regard. ${ }^{34}$ Far more successful, in comparison, were the efforts of Kemālpaşazāde and Ebū'ssu'ùd (d. 982/1574), who tried to harmonize the kānūn with the sharia by working out a comprehensive legal framework for what had been until then ad hoc administrative and fiscal arrangements and by rearticulating the principles of the Ottoman land regime in the language of Islamic jurisprudence. ${ }^{35}$

32 Tezcan, Ethics 118-120.

33 For the anonymous author's references to his participation in the Egyptian campaign, see Yücel (ed.), Osmanlı devlet, 125; for the other references to Egypt or "the Arab lands" (Arabistan), see Ibid., 94-95, 110, 123, 124; for the polemics against kānūn-minded conservatism, see Ibid., 93-94, 111, 118, 120-121; for references to (Ottoman) yasă̆, see Ibid., 98, 101-104, 109, 114. Note that Yücel misdates the text to ca. 1046-105o/1637-40; for the correct dating, see Tezcan, The "Kânûnnâme of Mehmed II" 658-659. The grand vizier addressed in the treatise must have been Rüstem Pasha (d. 968/1561), Semiz 'Alī Pasha (d. 972/1565), or Sokullu Mehmed Pasha (d. 987/1579).

34 Gel, XVI. Yüzyllın; Mandaville, Usurious piety.

35 İnalcık, Islamization; Akgündüz (ed.), Osmanlı kanunnâmeleri iv, 29-121; Imber, Ebu'ssu'ud esp. chs. 2 and 5 ; Buzov, The Lawgiver; on the relationship of kānün and sharia more 
As we shall see below, all three of these trends were relevant to the growth of an Ottoman corpus of siyassa shar iyya literature in the tenth/sixteenth century and informed the views expressed in this corpus. Still, of the first two texts to be written by Ottoman scholars on the topic, Cöngì's Risāla fí l-Siyāsa alshariyya (also known as Siyāsetnāme) was perhaps a more direct response to the challenges presented to the Ottoman officialdom by Syrian and Egyptian scholars, while 'Āşı Çelebi's Mi'rācü'l-eyāle ve minhāaü'l-'adāle was concerned more exclusively with the debates among the Ottoman Rumi elites. In line with their particular concerns, both also highlighted different strands of the earlier siyāsa shar'iyya corpus.

\section{Dede Cöngī and His Risāla fì l-Sìyāsa al-Shar ïyya}

The career of Kemālü'd-dīn İbrāhīm b. Bahşī b. İbrāhīm, known variously as Dede Efendi, Dede Halīfe, Kara Dede, or Dede Cöngī (on account of his popular commentary on a work on Arabic grammar written in cönk form) is a striking illustration of the high social mobility in the lands of Rum during the heyday of Ottoman expansion. Born to a modest family in Sonusa near Amasya in Anatolia, Cöngī had worked as a tanner before belatedly acquiring a madrasa education. Despite his modest background and late start, he subsequently had a rather successful career, serving as mudarris and mufti in different parts of the empire, including Bursa, Tire, Merzifon, Diyarbakır, Aleppo, İznik, and Kefe (Caffa). ${ }^{36}$ Since in both Diyarbakır and Aleppo Cöngī taught in a madrasa founded by Deli Hüsrev Pasha (d. 951/1544), it is reasonable to think that this vizier of Bosnian devşirme origin had been among his patrons. ${ }^{37}$ Another patron might have been Sultan Süleymān's eldest son,

generally, see also Barkan, XV ve XVIıncı asırlarda; Barkan, Kanun-nâme; Heyd, Studies; Repp, R., Qānūn and sharīa; Peirce, Morality tales; Ergene, Qanun and sharia; Peters, Crime and punishment.

36 On Cöngī's biography, see Akgündüz, Dede Cöngī; Ali b. Bâlî, El-Ikdü'l-manzûm 232-235; Atâyî, Hadâik i, 503-505.

37 Admittedly, Hüsrev Pasha had died a year before Dede Cöngī was appointed mudarris in the Hüsrev Paşa madrasa in Aleppo, but it is possible that the pasha's family remembered and honored the ties of clientage that had been formed between the two men after his death. While Hüsrev Pasha had served in numerous positions throughout his eventful career, it is noteworthy that his tenure as governor-general of Rumeli and then vizier (943-951/1537-1544) overlapped in time with the tenure of Ebū's-su'ūd as military justice (kāậīasker) of Rumeli (944-952/1537-1545). On the pasha's life, see Özcan, Hüsrev Paşa, Deli. 
Prince Mușțafā (d. 96o/1553), to whom Cöngī dedicated another treatise on fiscal matters. In other words, Cöngi was not just any provincial mudarris and mufti, but one with significant connections to the Ottoman military administrative elite. Cöngi’s commitment to the Ottoman religiopolitical order comes across clearly in the treatise he dedicated to Prince Muștafā, whom he addresses as "Sultan Prince Muștafā" and as "the inheritor of the office of caliph,"38 but it is more obliquely demonstrated in his Risāla fi l-Siyāsa al-shar'iyya for reasons that will be discussed below.

Unfortunately, we do not know at what point in his career Dede Cöngī penned his Risāla fi l-Siyāsa al-shariyya; the text provides no autobiographical information, and the earliest extant manuscript dates from 1054/16441645 , that is to say, almost 80 years after the author's death. ${ }^{39}$ It is tempt-

38 Dede Cöngī, Risāla fì Amwāli bayti-l-mālıb-2a; for a modern Turkish translation in slightly abbreviated form and the facsimile respectively, see Akgündüz (ed.), Osmanlı kanunnâmeleri iv, 217-218, 236-237. This treatise will not be discussed here, as there is no reference in it to either al-Siyāsa al-shar iyya or to any other work that draws on the latter text.

39 Dede Cöngī, Siyāsetnāme/Risāla fì l-Siyāsa al-shar'iyya sk, Ms Esad Efendi 3610/6, 156b164b (copied in 1054/1644-1645). Because the author does not mention his name within the text, the attribution to Cöngī has been based on the attribution of the vast majority of the later copyists and readers as well as the first translator of the work into Turkish. A minority of Ottoman readers and copyists, however, ascribed the work to other scholars. While most of these other attributions can be discarded as unfounded, one deserves further investigation. This is the attribution to the Egyptian Hanafi jurist Zayn al-Dīn Ibn Nujaym (d. 970/1563). Ibn Nujaym is identified as the author of Risäla fíl-Siyāsa alshar ciyya in three manuscripts preserved in Süleymaniye library (Ms Hacı Mahmud Efendi 1097/1, 14a; MS Hüsrev Paşa 758/3, 29a and MS, Reşid Ef 1027/13, 128a), while in two others in the same library (MS Carullah 2120/2 and Ms Laleli 961/4), he is identified as the author in the online library catalogue, but not in the manuscripts themselves. None of these manuscript copies are dated. Apparently, the text is attributed to Ibn Nujaym also in an undated manuscript preserved in Al-kutubkhāna al-Khidwiyya al-Mıșriyya, Ms Fiqh Hanafī 116o; for a description, see Dede Efendi, al-Siyāsa al-shar'iyya 18-19. What makes Ibn Nujaym an intriguing possibility is the fact that he was a contemporary of Cöngī and had a more nuanced view of the Ottoman imperial order than some other Egyptian scholars of the period. According to Samy A. Ayoub, Ibn Nujaym accepted Ottoman rule to be legitimate, but criticized "the corruption and abuse of power within it." He also engaged with the concept of siyāsa in his Bahrr al-räiq (The clear sea), albeit in a different manner from the Risāla fïl-Siyāsa al-shariyya. Whereas the treatment of siyāsa in Risāla fìl-Siyāsa al-shar iyya bears a strong imprint of the thought of the Mamluk-era Hanafi jurist Tarābulusī and, to a lesser extent, of the Hanbali jurist Ibn Qayyim al-Jawziyya, Ibn Nujaym took his definition of siyāsa from Maqrizī. Ibn Nujaym also vehemently rejected the roles played by kadis in the application of siyāsa in direct contrast to the author of the Risāla fílSiyāsa al-shar'iyya. On Ibn Nujaym's views on siyāsa and the Ottoman imperial authority, see Ayoub, Law, empire, and the sultan 54-64; for Cöngì's views, see below. 
ing to think, nevertheless, that Cöngī composed his text sometime during or after his stay in Aleppo (952-957/1545-1550), where he must have had many more opportunities to familiarize himself with the Mamluk-era siyāsa literature. Besides, from an article by T.J. Fitzgerald we learn that while he was serving as mudarris and mufti in Aleppo, Cöngī became involved in a major dispute that had the local scholars up in arms about the legitimacy of the fiscal practices that the Ottomans had been trying to establish there. In a fatwa he issued on the dispute, Cöngīhad firmly defended the legitimacy of the Ottoman practice, and the imperial administration had responded to the complaints in accordance with this fatwa. ${ }^{40}$ Even though there is no direct connection between this controversy, which was about fiscal matters, and Cöngì's Risāla fi l-Siyāsa al-shar iyya, which is about criminal law, the wider resentment about the Ottoman kānūn that the controversy revealed may well have provided an important motivation behind Cöngi's decision to pen this treatise.

Since Cöngī wrote his text in Arabic, and made little or no attempt to correlate the terms of Islamic juristic discourse with Ottoman administrative terminology, it seems safe to conclude that he was writing primarily for a scholarly audience, comprised of both Rumi and Arab scholars. If Cöngī intended with his text to reach out to the Syrian and Egyptian scholars in particular, his decision to frame the discussion around siyāsa shar iyya makes a great deal of sense: Siyāsa shariyya, after all, was a juristic concept that was well known to these scholars; it was also a concept well suited to the madhhab plurality that still prevailed in their circles; in fact, the proponents of the concept had downplayed madhhab differences in promoting siyassa justice, and especially valued the ability of the political authorities to rise above the confines of the madhhab system. ${ }^{41}$

At the same time, however, it could also be said that Cöngi did not do enough to reach out to the non-Hanafi Muslims. The vast majority of the sources he cites in his treatise (a total of 42 works) are by medieval Hanafi-Maturidi writers, many of them from Transoxania. ${ }^{42}$ As for those of his non-Hanafi sources that he identifies by name, there are no more than three. These are Ahkäm alsulțāniyya by Māwardī (d. 450/1058), who was a Shafi'i, al-Dhakhïra by Qarāfī, who was a Maliki, and an unidentified work (probably al-Ṭruq al-hukmiyya) by Ibn Qayyim al-Jawziyya, who was, like his teacher Ibn Taymiyya, a Hanbali. It could of course be symbolic that Cöngī chose a text each from the remain-

40 Fitzgerald, Murder in Aleppo 185, 188, 195-197.

41 Yllmaz, Caliphate 85.

42 For the complete list of the sources cited by Dede Cöngī, see Köksal, Fıkı ve siyaset 197200. 
ing Sunni madhhabs, but his reasons for choosing them might also have been simply the fact that they all dealt with the concept of siyassa shar iyya.

Strangely, however, Ibn Taymiyya's al-Siyāsa al-shar'iyya, generally assumed to have been among the sources of Cöngī, is actually nowhere referenced. ${ }^{43}$ Perhaps Cöngī found it more prudent to bypass this text because of the controversial nature of its author among the Arab and Rumi scholars he wished to reach. But it is also possible that Cöngī had simply not read Ibn Taymiyya's work, which was not as widely known in the lands of Rum at the time. ${ }^{44}$ In either case, there is no denying the presence of Taymiyyan ideas in Cöngìs epistle, but these ideas were transmitted via other Mamluk-era writers who had read and utilized Ibn Taymiyya rather than through Ibn Taymiyya's own works directly. An important connection in this regard was Ibn Qayyim al-Jawziyya, but even more important than him, as far as Dede Cöngī was concerned, was the aforementioned Hanafi jurist, Țarābulusī. Indeed, almost the entire introductory section of Cöngì's Risāla, in which he defines siyāsa, distinguishes between "just" and "unjust" siyassa, and introduces the concept of al-siyāsa alshariyya, was taken from the introduction to the third section of Tarābulusì's Muīn al-hukkām. ${ }^{45}$

Differently from Ibn Taymiyya, and in keeping with the Hanafi tradition, in this treatise Dede Cöngì uses siyāsa mainly in the narrower sense of administrative punishment. As the opening quotations from Bābartì (d. 786/1384) and Țarābulusī make clear, administrative punishments were understood to be harsher than the punishments prescribed by the sharia, as they were introduced with the aim of stamping out "corruption" ( fasād $).{ }^{46}$ Citing Ṭarābulusī, Cöngī points out that the topic of siyāsa is complicated and that Muslims fall into three groups in their position on the topic. One group rejects siyassa categorically because they mistakenly believe it to be against the sharia, while

43 Heyd, Studies in old Ottoman 199; Köksal, Flkıh ve siyaset 225; Sariyannis, A history 105. Differently from the other scholars, Köksal acknowledges that Ibn Taymiyya is not mentioned by name, but still assumes that Dede Cöngī utilized his text particularly in the early sections of the treatise.

44 To give an idea, no copy of Ibn Taymiyya's al-Siyāsa al-shar'iyya is mentioned in the 9o8909/1502-1504 inventory of the Ottoman palace library; for the facsimile and transliteration of the inventory, see Necipoğlu et al. (eds.), Treasures ii. Moreover, a preliminary codicological investigation of eleven of the twelve manuscript copies of Ibn Taymiyya's al-Siyāsa al-shar'iyya in Istanbul libraries suggest that none of these texts had come into the possession of Rumi readers before the mid-tenth/sixteenth century. See footnotes 125128.

45 Dede Efendi, al-Siyāsa al-shar'iyya 74-76; cf. Țarābulusī, Mu'ìn al-ḥukkām 138a-b.

46 Dede Efendi, al-Siyāsa al-shar'iyya 73. 
another group applies it too liberally and transgresses the punishments prescribed by God (hudūd), perpetrating "injustice" (zulm) and "blameworthy innovations" $\left(b i d a^{c}\right)$. Only a third group embraces the golden mean by combining siyāsa and sharia and practicing siyāsa shar 'iyya, defined as the kind of siyāsa that serves "shar'i ends" (al-maqāșid al-sharīa) and safeguards public order. $^{47}$

Cöngi next sets out to establish the legitimacy of siyassa shariyya on the grounds of evidence from the Quran and hadiths (nușūs al-shar'iyya) as well as with reference to the legislative deliberations of the four "rightly guided caliphs." Here, Cöngi furnishes textual proofs for the permissibility of specific siyāsa punishments. He also provides several more general explanations for why it had been necessary for later rulers to stipulate harsher punishments than what the sharia prescribed. He stresses in particular the mutability of shar $i$ judgments in connection with the idea of the "corruption of the times" ( fasād al-zamān), alluding to the pessimistic view of human history that had also informed Ibn Taymiyya's views on siyāsa. Accordingly, the further away Muslims are from the time of the Prophet, the more corrupt they become, thus necessitating the adoption of harsher measures to preserve public order. ${ }^{48} \mathrm{~A}$ second general principle that Cöngì evokes is al-mașăliḥ al-mursala, or social benefit, that he says had guided the first four caliphs when they introduced practices that the sharia neither permits nor prohibits, such as writing down the Quran ${ }^{49}$ As Hüseyin Yllmaz has pointed out, this concept was particularly important in the Maliki school of law, but its close cognate in the Hanafi legal school, mașlaha, had also been of central importance to the efforts of Ottoman jurists like Ebū's-su'ūd to legitimate controversial practices such as cash waqf s. $^{50}$

While modern scholars are in consensus that Dede Cöngī was writing all this to legitimate Ottoman ḳānūns, they have struggled to explain why he chose nonetheless not to reference either the Ottomans or their kānūns. The word qānūn and its plural qawānin are used several times in the text, but always in the sense of "principle" or "standard" (as in the principle of sharia or qānūn $a l$-shar ), which was the prevalent meaning of the word in the Mamluk con-

47 Ibid. $74-76$.

48 Ibid. 83. On the views of Ibn Taymiyya and Ibn Qayyim al-Jawziyya on fasād, see Belhaj, Law and order 409-412; for near contemporary Hanafi jurists' use of the same concept to accommodate legal change, see Reinhart, When women went to mosques 119-122; Terzioğlu, Bid'at, custom; for Shaf'i examples, see Katz, The "corruption of the times."

49 Dede Efendi, al-Siyāsa al-shariyya 84, 86.

$5^{\circ} \quad$ Yllmaz, Caliphate 86; Khadduri, Mașlaḥa 738-740; Mandaville, Usurious piety. 
text. ${ }^{51}$ Uriel Heyd has attributed the absence of pointed references to the Ottoman context in the treatise to Cöngì's authorial modesty and reluctance to go beyond the role of compiler. ${ }^{52}$ Perhaps, however, Cöngi wanted to write about administrative justice in the abstract language of jurisprudence, precisely because he thought this was a more effective way of winning over those of his readers who remained skeptical about the legitimacy of the yasa/kānün tradition. In any case, many of the specific examples of siyāsa justice that Cöngī discusses and condones in this text-for instance, execution by strangling, the use of torture to extract confessions, the consideration of the criminal record or of the social reputation of the accused as well as the admission of circumstantial evidence in determining guilt, "the acceptance of the killing of a few to avert harm to the many" (a principle referenced in "the kānūnnāme of Mehmed II" to justify royal fratricide), the execution of "perpetrators of discord ( fasād) on earth," and the punishment of "sodomy" as a capital crime-had their place in one fashion or another in the Ottoman kānün tradition as it had evolved until the time of Süleymān I (r. 926-974/1520-1566). In the Ottoman context, the criminalization of "sodomy" was a new development, initiated in the reign of Süleymān, which might explain why Cöngī mentions it multiple times in his treatise. ${ }^{53}$ Even in those instances in which the specific siyāsa punishment discussed was not part of the Ottoman penal code, its inclusion in the text could have contemporary relevance. For instance, considering that Cöngī was writing in a time of ongoing conflict with the Safavids, as well as of sporadic persecution of Anatolian "Kızlbaş," it must not be coincidental that the very first example of siyassa punishment that he gives from the beginning of Islamic history is the burning of a group of heretics (zanādiqa) by the fourth caliph 'Alī b. Abū Tâlib (d. 40/661) on grounds that they believed him to be divine. ${ }^{54}$ It must also be significant that Dede Cöngì does not go into the details of what kinds

51 Dede Efendi, al-Siyāsa al-shar'iyya 75, 84, 86. On the use of "qānūn" in the sense of "principle," or "standard," see Burak, Between the kānūn 7-8 and Ferguson, The proper order 72-74.

52 Heyd, Studies 202.

53 Dede Efendi, al-Siyāsa al-shariyya 77 (death by strangling), 78, 81-82 (punishment of "sodomites"), 90-92 (admission of circumstantial evidence), 92-94 (use of torture to force a culprit to admit crime), 103-104 (killing a few in order to avert harm to the many). For the relevant practices in the Ottoman kānūnnāmes, see Heyd, Studies 3o, 64, 77-80, 102103, 116-118; Akgündüz (ed.), Osmanlı kanunnâmeleri i, 328; iv, 296-298, 302, 369-370; for a comparison of the punishments prescribed for "sodomites" by jurists of different madhhabs as well as by ḳānūn, see el-Rouayheb, Before homosexuality 118-128.

54 Dede Efendi, al-Siyāsa al-shariyya 77-78. On this anti-ghulät report, see Anthony, The caliph and the heretic 161-194. 
of siyāsa punishments he considered "unjust" or "un-shar ¿," as this could have brought up controversial aspects of the Ottoman penal code-for instance, the substitution of some of the corporal punishments with fines-as examples of "unjust" or "un-sharī" punishments. 55

After having legitimated law making by the political authorities, Cöngī turns in the next section of his treatise to the question of whether it is legitimate for kadis to practice siyassa, namely, to apply the laws and regulations introduced by rulers. This, too, was a critical question, since in the Ottoman legal system kadis were responsible for applying kānūn as well as sharia and since notwithstanding the alternative venues of justice distribution, such as the Imperial Court and courts of governors-general, where kadis (or ḳädīaskers) also presided, the Ottoman rulers actively promoted the kadi courts as the principal venue of justice distribution throughout their realms. ${ }^{56} \mathrm{In}$ this context, it should not be surprising that Cöngi answers the question of whether kadis can practice siyāsa with an overwhelming yes, albeit a yes uttered by citing others. First, he cites a passage from Ibn Qayyim al-Jawziyya to the effect that the sharia has not determined limits for how siyāsa is to be practiced; because rulers will introduce laws and regulations in response to the specific conditions of the time, when those conditions change, so can the rules. Hence, in some periods and places kadis may be delegated the functions of military governors, while in other periods and places they may not. Next, Cöngī gives us the contrary view upheld by Māwardī and Qarāfì that kadis should not meddle in siyāsa, and he lists nine reasons why these two jurists considered military governors to be equipped with greater powers than kadis to practice siyāsa and deliver effective justice. In the end, Cöngī gives his own view, based on the authority of "the principal Hanafi sources," that kadis have also been granted most of these powers. ${ }^{57}$ Once again, Cöngi was tacitly approving of the ways in which the Ottomans administered justice.

To recapitulate, Cöngì's Risāla fi l-Siyāsa al-shar iyya was an attempt on the part of a devoted member of the Ottoman learned establishment and a Rumi Hanafi scholar to intervene in the debates that were ongoing among both Syrian and Egyptian, and to a lesser extent Rumi, scholars about the legitimacy of

55 For a different interpretation, see Midilli, Dede Cöngi'nin 241, 244-255.

56 For a nuanced discussion of the Ottoman justice distribution and promotion of kadi courts as its principal venue in the tenth/sixteenth century, see Peirce, Morality tales 86$125,311-348$. On the place of kadi courts versus other venues of justice distribution in the early modern Ottoman Empire, which reflect a different, twelfth/eighteenth-century perspective, see Ergene, Local court, ch. 9, Aykan, Rendre la justice 52-86, Tuğ, Politics of honor 185-244 and Baldwin, Islamic law, chs. 2, 3, and 5 .

Dede Efendi, al-Siyāsa al-shar'iyya 105-120. 
the Ottoman kinnūn. I have argued above that it was probably in an effort to win over his colleagues opposed to the "Ottoman yasağ" that Cöngì defended the Ottoman kānūn through the juristic framework of siyāsa shar 'iyya and avoided making direct references to specific Ottoman institutions. Possibly, it was also his desire to "play safe" and avoid unneeded controversy that led him to bypass Ibn Taymiyya's al-Siyāsa al-shar'iyya while making his arguments. Interestingly, a second Ottoman Rumi writer to take an interest in the siyāsa shar'iyya literature slightly later in the same century would opt for a very different strategy, translating Ibn Taymiyya's al-Siyāsa al-shar 'iyya into Turkish and adding extensive (and critical) commentary about the contemporary Ottoman context.

Es-Seyyid Pīr Meḥmed b. Seyyid 'Alī, better known as 'Āşılk Çelebi, represents a rather different social and intellectual profile from his older colleague, Cöngī. To begin with, 'Āşı̣ was a Rumelian, born in Prizren (in present-day Kosovo) to a distinguished ulema and seyyid family with distant Baghdadi roots, and received his education from the leading scholars of Istanbul. Partly because he made his career in a time of increasing congestion in the Ottoman learned establishment and partly because of his own circumstances, however, 'Âşlk had a rather undistinguished career, having to work for many years as a court clerk, a trustee for pious endowments, and a secretary to the şeyhül-islām before eventually settling for an equally frustrating career as a small-town kadi. As 'Āşı makes clear in the Mirāäül'-eyāle, he took greater pride in his accomplishments as a belle-lettrist, "a poet and a prose-stylist," than as a kadi. ${ }^{58}$ In keeping with his penname 'Āşık (meaning, literally, lover), his literary oeuvres included a Dī̄ān, a şehrengīz ("city thriller"), devoted to the beautiful young men of Bursa, and several biographical dictionaries, the most famous of which is his Meşā'irü'ş-şu'arā, a lively tribute to the empire's poetic scene as well as to its urban culture of predominantly male lovers and beloveds. He also translated into Turkish a number of religious, political, and literary works from Arabic and Persian. ${ }^{59}$

58 Âşık Çelebi, Mirấcül-eyâle $55^{-56 .}$

59 In addition to Ibn Taymiyya's siyāsa al-shar'iyya, 'Āşı̣ Çelebi translated into Turkish the Arabic version of Abū Ḥāmid al-Ghazalī's (d. 505/1111) al-Tibr al-masbūk fì nașīhat almulūk and Muhyyìd-dīn Hațībzāde's (d. 940/1534) Raw ḍ al-akhyār, which was an abridged compilation of those chapters of Zamakhsharī's (d. 538/1144) Rabī l-abrār that deal with rulership. Probably 'Āşı chose to translate these works because of their popularity with Ottoman readers. 
There is no indication that 'Āşık ever read Cöngì's epistle, so it is impossible to say whether it was that work that first piqued his interest in the siyassa alshar 'iyya literature. Unlike Cöngī, 'Āşı had not spent time in the former Mamluk lands, but he had studied with at least one traditionalist scholar from Egypt, and it has been speculated that he might have gained familiarity with the works of Ibn Taymiyya through him. ${ }^{60}$ In the preface to his translation, 'Âşlk describes al-Siyassa al-shariyya as a "book that is small in volume but great in benefit," and he explains that he decided to translate it to fulfill the Quranic injunction to "command the right and forbid the wrong" and to petition for a more desirable post for himself. 'Āşı was writing in 977/1569-1570, one year after he had been dismissed from his office as kadi of Karatova (Kratovo, today in the Republic of North Macedonia), and he was clearly very disillusioned with his career in the Ottoman judiciary. He expresses hope that if Selīm II (r. 974-982/15661574) is pleased with his translation, he may free him from all administrative duties to devote his time entirely to the composition of literary works, but 'Āşık was also willing to be examined with the prospect of employment at either the land registry or in the department for the inspection of tax farms. ${ }^{61}$ Perhaps because he was not sure of a favorable reception by Selīm II, 'Āşsk also addresses the grand vizier Sokollu Mehmed Pasha in the conclusion to his translation. ${ }^{62}$ Sokollu, to whom 'A̧sıl had also devoted other works, was the most powerful Ottoman statesman at the time, as well as an active patron of literature and the arts, and a pious Muslim, whose brand of Sunni religiosity combined a high respect for the sharia with devotion to sharia-abiding Sufism. Sokollu and his royal wife İsmihān Sultan (d. 993/1585) were ardent admirers and patrons of the Rumelian Halveti master, Muṣliḥu'd-dīn Nūre'd-dīnzāde (d. 981/1574), who was (as discussed in Grigor Boykov's paper in this volume) a vocal advocate of the state-sponsored version of Sunni Islam. ${ }^{63}$ Around the years 'Āşık translated alSiyāsa al-shar'iyya, Soḳollu had also invited to Istanbul Birgivī Meḥmed Efendi, whose works would later inspire the Kadızadelis, to solicit his words of advice

6o His teacher, 'Abd al-Rahīm al-'Abbāsī (d. 963/1556), of the 'Abbasid family, was a hadith scholar who had come to Istanbul from Cairo following the Ottoman conquest. He was, by lineage, a Hanbali, but had switched over to the Shafi'i school at a later point in his life. On this scholar, see Öznurhan, Abbâsî, Abdürrrahîm 5-6 and Pfeifer's essay in this volume; for the argument that 'Abbāsī may have been the conduit by which both Çivizāde and 'Āşı̣ discovered Ibn Taymiyya, see Gel, XVı. Yüzyılın 182.

61 Âşık Çelebi, Mirâcü'l-eyâle 56-57; for the date of composition, see ibid. 203-204.

62 Ibid. 232. For another work 'Āşı presented to Soḳollu, see 'Āşık Çelebi, Dhayl. For another eulogistic mention of the grand vizier, see Âşık Çelebi, Meşấirü'ş-şu'arâ iii, 1179.

63 On Soḳollu and İsmihān's patronage of Nūre'd-dīnzāde, see Necipoğlu, The age 345-368 and Yürekli, A building 159-185. 
about "how to eliminate injustices" (def'-i mezālim) in the Ottoman realms. ${ }^{64}$ Given Sokollu's interest in a range of sharia-minded interlocutors, it is not surprising that 'Āşık Çelebi thought the grand vizier might also be interested in his translation of Ibn Taymiyya's al-Siyāsa al-shar'iyya.

The text that 'Âşı presented to Selīm and Sokollu for approval, however, was more than a simple translation. In the early modern Ottoman world of letters, translators played a role more akin to that of an author, replacing the original preface, and often also the original title of the work, with one of their own, and depending on their target audience, their own intentions, and the conventions of the genre, they could translate the source text in markedly different ways. ${ }^{65}$ 'Âşı claims that he translated Ibn Taymiyya's epistle "word for word" (bi-ibâretihi) and without embellishing it with verses or rhymed prose. ${ }^{66}$ In fact, his was not a literal translation but rather a transadaptation, which enriched the content with additional material. The sections added by 'Āşı, including his introduction and conclusion, as well as the excursuses on kadis and kadiship, the land regime, fiscal practices, and the art of warfare, are almost as long as the original text, and significantly alter the overall impression of the work.

The introduction is revealing of both similarities and differences between the author and the "translator" in religious and political outlook. Even though 'Áşı w was, in his personal life and cultural sensibility, quite different from the stringent Hanbali scholar, he agreed with Ibn Taymiyya that the proper functioning of society required religion and law, the upholding of which in turn required a strong state. To drive home this point, Ibn Taymiyya had begun his treatise with the famous "authority verse," "O you who believe, obey God and the Messenger, if you believe in God, and those in authority among you" ( $Q$ 4: $\left.5^{8}-59\right)$, and 'Āşlk also incorporates this section into his own introduction. For both men, figures of authority comprised both the military ruling elites and scholars, even though in the introduction to his transadaptation 'Āşlk puts the stress more squarely on rulers as the deputies of the prophets in the postprophetic age. ${ }^{67}$

Differently from Ibn Taymiyya, 'Āşı tailored his discourse to a distinctly royal audience and devoted a good chunk of his introduction to the eulogy of the Ottoman rulers. After praising God, the Prophet, the four "rightly guided"

64 Atâyî, Hadâik i, 633 .

65 Hagen, Translations $95^{-134 .}$

66 Âşık Çelebi, Mirrâcü̈l-eyâle 57 .

67 Ibn Taymiyya, al-Siyāsa 18-19, 161/Ibn Taimiyya 12-13, 183; cf. Âşık Çelebi, Mi'râcül-eyâle $40-41,183$. 
caliphs, and the Companions, he provides a brief account of human history from Creation until the time of the Ottomans with the aim to highlight the unique place of the latter within world and Islamic history. Therein the various Muslim dynasties are listed without any distinction being made between those that claimed the universal caliphate, such as the Umayyads and the 'Abbasids, and those that were mere regional emirates or sultanates, like the Ghaznavids, Buyids, or Seljuks. The Buyids, who were Shi'ites, are listed among the Muslim rulers who occupied themselves with matters of "justice and sharia," whereas "Chinggis from among the infidels (kefereden) and Timur from among the oppressors (zalemeden)" are mentioned separately as rulers who were sent by God to punish the wrongdoers, but on account of whom many innocents also suffered. ${ }^{68}$ The Ottomans are introduced as having inherited "the office of the caliphate and the protection of the seal of prophecy" (emr-i hilâfet ve hıfz-l hatm-i nübüvvet). ${ }^{69}$ 'Asşı w was evoking here a Sufi-inflected definition of the caliphate and casting the Ottoman rulers as "caliphs of God," who, like the first four caliphs, took their authority directly from God and who united in their person spiritual and temporal power. ${ }^{70}$ In clear contrast to Ibn Taymiyya, albeit in good company among his Ottoman contemporaries, 'Âşlk even attributes quasi-mystical qualities to the Ottoman rulers. The recently deceased Süleymān I is eulogized as a ruler who had "won with his sword not just the sultanate of this world but also the sultanate of the other world and in whose sainthood (vilâyet) and ability to perform marvels (kerâmet) the people have great faith." ${ }^{71}$ Esoteric themes also predominate in 'Āşlḳ's eulogy for Selīm II. Possibly in order to assuage popular misgivings about Selīm, who had acceded to the throne after his father had controversially ordered the execution of two of his brothers, 'Âşık writes for several folios about the esoteric properties of the name "Selīm" and (wrongly) prophesies that the latter would remain on the throne for 40 years. ${ }^{72}$

The emphasis on the Ottoman dynastic pedigree in 'Āşlk's text also stands in contrast with the inconsequential place of the dynastic principle in Ibn Taymiyya's original epistle as well as in Mamluk political culture at large. ${ }^{73}$ Actually, genealogy was not one of the strong points of the Ottomans in their

\footnotetext{
68 Âşık Çelebi, Mirấcü'l-eyâle 41.

69 Ibid. 42.

70 On the importance of Sufi themes in tenth/sixteenth-century Ottoman political thought and culture, see Yilmaz, Caliphate.

71 Âşık Çelebi, Mirrâcü'l-eyâle 46.

72 Ibid. 46-55.

73 On the limited role of dynasticism under the Mamluks, see Ayalon, Mamlūk military aristocracy 205-210; Holt, The position; Levanoni, The Mamluk conception; Richards, Mamluk amirs $36-37$; Yosef, Mamluks and their relatives.
} 
claims to preeminence in the Islamic world, either. Notwithstanding, 'Āşı asserts categorically, if vaguely, that the Ottomans come from a line of prophets and do not have any fire-worshippers among their ancestors, whereas all the other "sultans of the past" were either Chinggisids or Circassians (a reference to the Mamluks), and even the best of them were at the end of the day descendants of Chosroes (Nûşînrevan), who was a follower of Zoroaster and a fire-worshiper. ${ }^{74}$ The underlying message was that the Ottomans are and have always been better, purer Muslims than other dynasties. Even though the Safavids are not directly referenced, given their rule over Iran, and given Iran's history as the original homeland of Zoroastrianism, 'Āşık's division of royal houses into those that descended from the monotheistic prophets and those that descended from the followers of Zoroaster and fire-worshippers must have been colored, to a large degree, by the ongoing Ottoman-Safavid rivalry.

Otherwise, however, 'Âşı does not stress the Ottoman claim to be champions of Sunni Islam in his eulogy, or at least not as much as did some other contemporaries. ${ }^{75}$ In fact, he downplays the importance of religious motivations when extolling the Ottoman military victories in general. This is interesting, because the long-standing Ottoman claim to be $g \bar{a} z \bar{\iota}$ s, waging war in the name of Islam, would have fit well into a Taymiyyan framework, in which jihad is one of the primary duties of a Muslim ruler. ${ }^{76}$ Instead, Āşık builds his narrative around the Ottoman quest for world dominion. This ideal arguably had its heyday somewhat earlier, in the first three to four decades of the tenth/sixteenth century, when the Ottomans were expanding rapidly, and is thought to have died a slow death thereafter. ${ }^{77}$ Nevertheless, when 'Āşlk was writing, the Ottomans were still actively trying to extend their influence over distant territories by using the instruments of diplomacy and trade, and Sokollu was

74 Âşık Çelebi, Mi'râcül'-eyâle 42. For broader perspectives on Ottoman royal genealogies in the tenth/sixteenth century, see Flemming, Political genealogies.

75 For a slightly later Ottoman text that mentions the Ottoman sultans' devotion to Sunni Islam and the Hanafi madhhab as the first of the 20 qualities that made them superior to other dynasties, see Ta līḳīzāde, Ta līḳīzāde’s Şehnāme 116.

$76 \quad G a z \bar{a}$ does, nevertheless, surface as a theme in the treatise of advice 'Āşı appended to the very end of his supplements. This treatise, presented as a text that was written by Aristotle for Alexander the Great, is a Turkish translation of an Arabic text with some references to contemporary Ottoman practices. For the references to gazā, see Âşık Çelebi, Mirrâcü'l-eyâle 211, 213; for the complete treatise, see 211-231; for the original Arabic text and another Turkish translation made in the reign of Mehmed III (1003-1012/1595-1603), see İhsanoğlu, Osmanlı askerlik literatürü ii, 686-687.

77 On the Ottoman aspirations for world conquest during the early part of the long reign of Süleymān, see Fleischer, The Lawgiver; Necipoğlu, Süleyman the Magnificent; Turan, The sultan's favorite; Şahin, Empire, ch. 6. 
contemplating such ambitious projects as building a canal between the Don and Volga Rivers and over the Suez to connect with the Muslim communities that lived in the steppes north of the Black Sea and in the Indian Ocean. ${ }^{78}$ 'Āşık stresses the continuing Ottoman claims to world dominion by hyperbolically writing of the Ottoman arrows reaching as far east as Eastern Turkistan (Mâçîn) and the Indus valley (Sind) and as far west as Rome. It is only at the end of a long list of victories and conquests that he signals the Ottoman championship of Islam with a reference to the (fancied) destruction of the "great church" in Rome. ${ }^{79}$

'Âşlk's eulogy of the Ottomans comes closer to the Taymiyyan line when he praises the Ottomans for their devotion to justice and the sharia. Even here, however, there is an important difference between the two writers. Whereas Ibn Taymiyya categorically rejects the possibility of justice outside the bounds of the sharia, 'Asşık does not. Rather, he uses Sufi metaphors, as he eulogizes the Ottoman rulers for being the "meeting place of the two seas" (mecma 'ü'lbahreyn) and for uniting the "two lights" of justice and sharia. He also praises them for having issued "well-respected kânuns like the resm-i Osmânî" this indicates that, like the Arab jurists of the tenth/sixteenth century, 'Âşık saw the Ottoman keānūn as representing a form of justice beyond the sharia, but he differed from them in that he saw this in a positive light.

As we read the later sections of the text, however, it becomes apparent that 'Āşı did not actually consider the Ottoman administrative and legal system of his time either as just or as shar $\bar{\imath}$ as he makes them out to be in his introduction. This critical streak becomes apparent already in 'Āşıł's translation of the first chapter of Ibn Taymiyya regarding the appointment of the right people to public offices. After a fairly conventional discussion of what Hanafi jurists have said about the permissibility of serving as kadi, ${ }^{81}{ }^{\prime} \bar{A} s ̧ ı$ p provides a sharply critical account of the Ottoman judiciary of his time. According to him, some of the kadis of his time lacked the requisite "knowledge and understanding" to perform their duties properly, while some others were learned, but did not act in accordance with their learning, disregarded what their "reason and religion" dictated in return for monetary gain, and justified their unlawful decisions by saying that this is what "the grandees" (ekâbir) demand. Though a kadi himself, 'Āşı mocks the false pretensions of corrupt kadis to piety with almost anticlerical overtones. He describes how kadis give themselves airs with their long

78 Casale, The Ottoman age, ch. 5 .

79 Âşık Çelebi, Mi'râcü'l-eyâle 44.

8 o Ibid. 42.

81 Ibid. 69-79. 
gowns and unkempt beards in supposed imitation of the Prophet (who, 'Âşık assures us, looked nothing like them) and how they use this aura of respectability to have their way with male and female beloveds. In keeping with his çelebi sensibility, 'Âşık ends this discussion on a humorous note with a couplet about how he would like the same treatment but is always passed over because he has a sparse beard. ${ }^{82}$

Perhaps because he was hoping to be given a job in the fiscal bureaucracy and wanted to prove his competency, 'Āşı makes the most extensive interpolations on the subject of the public treasury (beytül-mâl). These interpolations, which are mostly in the "supplements" (ilhâkât), can be seen as serving two different, and to some degree even contradictory, purposes. On the one hand, a principal concern of 'Áşsk seems to have been to demonstrate the shar'i basis of the Ottoman system of land tenure and taxation, and he does so by reproducing the fatwas issued on the topic by Ebū's-su'ūd. As the latter's one-time student and secretary, 'Āşı is profuse in his words of praise for Ebū's-su'ūd and hails the latter as "the imam of our time, the chief mufti of the ulama and the general public (âmme), the seal of the müctehids and remnant of the righteous selef." ${ }^{3}$ On the other hand, 'Āşlk also includes in his text three documents that he takes to be from the earliest days of Islam and that inform the critique he provides of the actual working of the Ottoman fiscal system further down in the text. ${ }^{84}$ In addition, 'Āşı k draws on his professional experience as a midranking

82 Ibid. 84-88.

83 Ibid. 198-201.

84 Ibid. 192-198. The documents in question are 1) an "ahidnâme" sent by the Prophet Muhammad to the generality of Christians, 2) an "ahidnâme" sent by the Christians of Damascus and Aleppo to 'Umar b. al-Hațtāb (d. 23/644), and 3) a letter sent by the Prophet Muhammad to Bahraan of Yemen. The first of these documents is actually identical to the charter that had been preserved by the monks of St. Catherine in Mt. Sinai and which would be used by them multiple times to defend their foundations against state encroachment. Since in the charter in question Muhammad promises to Christians that Muslims would not interfere with the appointments of church officials, destroy or confiscate church properties, or use them to build mosques, this document relates directly to 'Āşı '̧'s critique of the Ottoman confiscation of Christian endowments, discussed below. For differing perspectives on the "charter" and its authenticity, see Moritz, Beiträge; Atiya, The Arabic manuscripts; Morrow, The covenants. For other contemporary Ottoman documents that cite the "charter," see Acun, Osmanlı İmparatorluğu'nda and Ferīdūn Bey, Münşe'ātü's-selāțīn, SK, Ms Ragip Paşa 1521, 20b-21a. The second document included by 'Āşı is a version of the so-called "pact of 'Umar." On the complex history of this document and its multiple versions, see Cohen, What was the Pact of 'Umar? As for the third document, 'Āşı says he took it from Abū Yūsuf's (d. 182/798) Kitāb al-kharāj, a text that would become progressively more important for the way the Ottomans understood their land regime in the eleventh/seventeenth century. 
kadi in the Balkans both to explain the particularities of the complex system of land tenure in that region and to critique a wide variety of "abuses" he witnessed during his tenure in Rumeli. ${ }^{85}$ While some of these "abuses" must have been the result of officials taking advantage of a monetizing economy to enrich themselves at the expense of the re' $\bar{a} y \bar{a}$, as 'Āşlk suggests, others were clearly connected to the central administration's attempt to alleviate fiscal tensions in a time of rising expenses. A recurring theme in 'Āşlḳ's criticisms is the overtaxation of the subject population. In this, the şeyhü'l-islām Ebū's-su'ūd himself was complicit, having ruled all arable lands in the Ottoman Empire to be "royal demesne" (arâziyü'l-memleke) and having legitimated on that basis the imposition of "tithing rates higher than the customary 10\%." 'Âşı did not find it in himself to challenge these rulings and instead puts the blame squarely on the tax collectors for abusing their privileges. By dispossessing the re $\bar{a} y \bar{a}$ of their baştinas and by overtaxing the Christian peasants until they are forced to flee, avaricious officials are both violating shari $\bar{\imath}$ norms and causing damage to the public treasury, he argues. ${ }^{87}$

Another practice that 'Aş̧ı blames on greedy officials is the sale of properties belonging to Christian ecclesiastical foundations (kilise evkāfi). Even though 'Āşlk accuses the superintendents (nâzır) who sold such waqfs of proceeding without proper authorization, actually, the practices that he criticized were also the result of state action. ${ }^{88}$ In 1568 , shortly before 'Âşık penned his transadaptation, the Ottoman government, citing a number of fatwas by Ebū'ssu'ūd, had declared all Christian waqfs to be null and void. Subsequently, however, after some hard negotiation with the monastic authorities, and again with Ebū's-su'ūd's help, the government had softened its position. Christian waqfs would once again be allowed to function, but under the legal fiction that they were benefiting Christian communities rather than Christian places of worship (which the şeyhül-islām had earlier ruled to be impermissible). Following this revised formula, churches and monasteries would also be permitted to "buy back" their properties, albeit at considerable cost to these foundations. ${ }^{89}$ Around the time 'Âşl was writing (977/1569-1570), the imperial authorities had already revised their stance, but in various parts of the empire the complex

\footnotetext{
85 Âşık Çelebi, Mirâacül-eyâle 201-211.

86 Imber, Ebu's-su'ud 124-125; Greene, The Edinburgh 68.

87 Âşık Çelebi, Mi'râcü'l-eyâle 202-204.

88 Ibid. 206.

89 On the "crisis of the monasteries," see Fotić, The official; Alexander, The Lord giveth; Kermeli, Ebū's-su'ūd's; Kermeli, Central administration; Kolovos, Christian vakıfs. For the fatwas issued on this issue, see Ebū's-su'ūd, Şeyhülislâm 163-164, 168-169.
} 
processes of confiscation and resale were still dragging on. ${ }^{90}$ It was probably this fluctuating state of affairs that enabled 'Āşı to to present the sale of Christian waqfs as an "abuse" by individual officials rather than as concerted state action. Even though 'Āşı w would not necessarily have known of this, Ibn Taymiyya had also played a role similar to Ebū's-su'ūd in the confiscation of Christian monastic foundations in the Mamluk sultanate two and a half centuries earlier. ${ }^{91}$ Hence, there is a delicious irony in the fact that 'Asşılk presents his criticism of the sale of church waqf s in a translation of a work of Ibn Taymiyya's as well as after praising Ebū's-su'ūd. 'Āşlḳ's remarks on the sale of church waqfs are, nevertheless, important as a rare piece of evidence of the critique of this affair by a Muslim.

In comparison to the matter of the public treasury, 'Āşık did not have much to add to Ibn Taymiyya's discussion of penal law. He does, however, make a few omissions in the original text, presumably out of consideration for the sensibility of his high-placed readers. One of the omitted passages concerns the question of whether the murder of a sovereign ruler should be considered a crime against "the rights of God," that is to say, a public crime whose punishment is incumbent on the political authorities. Even though 'Āşık was writing half a century before the first instance of regicide in the Ottoman lands, he must have found the topic too distasteful to include in a text submitted to the Ottoman sultan. ${ }^{92} \mathrm{~A}$ second omitted paragraph deals with the question, "If one Muslim ruler enters the territory of another, and kills that land's people, is it incumbent on that country's people to resist or should they submit?" As the question exposed the power grab behind conflicts between rival Muslim sovereigns, even the otherwise outspoken Ibn Taymiyya had found it prudent not to venture an answer and simply noted that Hanbali jurists have differed on the matter. The Hanbali reference would, of course, have been irrelevant to 'Āşı ḳ's overwhelmingly Hanafi audience, but more consequential was the possibility of legitimate resistance to an invading Muslim power that the question raised. Since the Ottomans had repeatedly been in the position of the invading power in their recent history, the question was not one they would have wished to entertain, hence the omission by 'Âşlk. ${ }^{93}$

\footnotetext{
9o Kermeli, Central administration.

91 Sariyannis, A history 104-105; on Ibn Taymiyya's fatwa on church waqfs, see Welle, The status.

92 This omission was first pointed out by Köksal, Fık h ve siyaset 171; for the original text, see Ibn Taymiyya, al-Siyāsa 9o/Ibn Taimiyya 98.

93 This omission was first pointed out by Köksal, Fikı ve siyaset 171; Ibn Taymiyya, al-Siyāsa 93/ Ibn Taimiyya 102.
} 
A third omission of 'Āşlk's is seemingly minor but nevertheless illustrative of the difference of outlook between him and Ibn Taymiyya. Ibn Taymiyya begins the section on the punishment of wine-drinking with a hadith, which has the Prophet say that if someone is caught drinking wine once, twice, or three times, he should be flogged, but if he is caught drinking a fourth time, then he should be killed. In his commentary on the hadith, Ibn Taymiyya says that most scholars consider the Prophet's reference to the execution of the habitual wine-drinker to be "abrogated" (mansükh), some other scholars consider the punishment to be still valid, and yet others hold it to be a discretionary punishment to be decided upon by the ruler $(t a \underline{z} z \bar{r} r)$. 'Āşı translates the passage as is, except he omits the opinion of those scholars who held the punishment of execution to be still valid. Presumably he considered this opinion to be too extreme. ${ }^{94}$ Otherwise, however, 'Āşlk translates Ibn Taymiyya's harsh prescriptions for the punishment of wine-drinkers, adulterers, and "sodomites" without any mitigating commentary, despite the fact that he himself was an aficionado of wine parties and beautiful youths and makes no secret of it in his literary writings and, to some degree, even in this transadaptation. ${ }^{95}$ His reticence in this regard is of course not surprising, since it was a far more serious crime to question shari regulations than to break them. What is perhaps more interesting is that 'Āşlk also translates faithfully Ibn Taymiyya's strongly worded condemnation of the conversion of hadd punishments into monetary fines, even though this was a common practice in the Ottoman lands. In fact, where Ibn Taymiyya likens the people who collect fines for hadd offenses to whores, pimps, and fortunetellers, the Ottoman writer not only translates these insults as they are but also volunteers both the Turkish and Arabic words for "pimp." It would seem that 'Āşı translated these sections approvingly, because they meshed well with his own dislike of the pecuniary concerns of the Ottoman officials of his time.

There is finally one passage in which 'Āşık indicates, in a fascinating aside, that the Hanbali scholar was not always harsher than the Ottoman learned establishment on questions of penal law. The passage in question concerns the punishment of the perpetrators of religious innovation (bid'a). In the original passage, Ibn Taymiyya first cites the opinions of Shāfi 'i, Aḥmad, and Mālik, that "the initiator of innovations which are contrary to (the precepts in) the Book and the Sunna be put to death"; he then adds that "Mālik and some other jurists

94 This omission was first pointed out by Furat, Selefiliğin 221; compare Ibn Taymiyya, alSiyāsa 109-110/Ibn Taimiyya 120 and Âşık Çelebi, Mi'râcü'l-eyâle 145-146.

95 Âşık Çelebi, Mi'râcül-eyâle 144-149.

96 Ibid. 125-126; cf. Ibn Taymiyya, al-Siyāsa 76-8o/Ibn Taimiyya 79-82. 
allowed that the Qadariyya be put to death, for fear that mischief might spread in the land and not because they are apostates." After translating this passage, 'Āşı comments, "It is the same with the Kharijites and Revâfiz (a derogatory term for Shi'ites); [their persecution] is not on account of their apostasy (riddetlerinden) but because they might perpetrate mischief, but it is understood from the fatwa issued by the current mufti of the believers, the imam of the Muslims, the chief mufti, the prop of the religion of the Prophet ... the remainder of the müctehids ... Ebū's-su'ūd, which rules it permissible to enslave the Kızılbas women, that the latter are murdered on account of their apostasy."97 With this interjection, 'Āşlk not only confirms that in the tenth/sixteenth century some members of the Ottoman learned establishment considered the Kızlbas to constitute a different category of "heretics" than Shi'ites, ${ }^{98}$ but also that the official Ottoman position on the Kızlbaş was even harsher than that taken by Ibn Taymiyya on other "misbelievers." The latter point is striking, because the Hanafi school, to which the Ottomans belonged, had previously been the most lenient of the Sunni legal schools when it came to the persecution of heretics and misbelievers. As such, 'Āşık's commentary reveals how much the Hanafi position on the matter had hardened by his time, due in part to the polarizing effect of the Ottoman-Safavid conflict and in part to the fact that in the Ottoman lands Hanafism had become a veritable "state madhhab."99 Even though 'Āşı himself was not particularly confessionally minded, ${ }^{100}$ as a member of the Ottoman learned establishment he could hardly avoid the obligatory anti-Kızılbaş rhetoric of his time. In fact, the reference to Ebū's-su'üd's fatwa is not the only instance in which 'Āşık bows down to anti-Kızılbaş rhetoric in this text. In his "supplements," he also includes a letter purported to have been written by 'Alī b. Abū Ṭālib, in which the latter praises the second "rightly guided" caliph, 'Umar, to critique the "Kızılbaş," who accept 'Alì to be their imam but who reject 'Umar as caliph. ${ }^{101}$

97 Âşık Çelebi, Mirấcül-eyâle 150-151; cf. Ibn Taymiyya, al-Siyāsa 119/Ibn Taimiyya 130-131. For a foray into the genealogy of the notion of "perpetrators of mischief in the land" $(s \bar{a} \bar{\imath}$ bi-l-fasādfíl-'arż), see Aykan, A legal concept.

98 Ebū's-su'ūd actually states this explicitly in one of his fatwas; see Ebū's-su'ūd, Şeyhülislâm 174-175. Other jurists in other contexts, however, made the Shi'ite-Kızılbaş distinction differently, as did the political authorities; see Winter, The Shiites 12-20; cf. Imber, The persecution 245 .

99 Burak, The second formation.

100 Cases in point would be his views on the Buyids, discussed above, and his views on antinomian dervish poets, discussed in Anetshofer, Meşấirü̈ş-Şu'arâ.

101 Âşık Çelebi, Mírâcüll-eyâle 208. 
Clearly, 'Āşıłks Mi'rācü'l-eyāle was less a programmatic endorsement of Ibn Taymiyya's vision of siyassa al-shar 'iyya than a somewhat idiosyncratic engagement with it in the early modern Ottoman context. Ultimately, 'Āşık’'s "constitutional" views (his endorsement of a realm of justice beyond the sharia, and his more mystical conception of royal authority) were more "Ottoman" than "Taymiyyan"; it was more in his critique of specific Ottoman practices that 'Āşık turned "Taymiyyan." Both of these strains of 'Āşlḳ's thought had something to do with the shifting social, political, and cultural currents in the late tenth/sixteenth century. For 'Āşı was, on the one hand, a vivacious chronicler of an "age of beloveds," in which the elites of an expanding Ottoman Empire embraced the ideals of world conquest, charismatic authority, and spiritualized love, and could transition seemingly effortlessly between the prescriptive language of religious law and the ambiguous idiom of Neoplatonic Sufism. ${ }^{102}$ On the other hand, this age was already slowly withering when 'Asşı was writing, and in the new age of "crisis and transformation," of diminishing opportunities and rising competition, and we might add, of deepening rifts in approaches to religion and piety, the Ottoman elites would also feel the need for a new approach to law and governance.

Afterlives of the Sixteenth-Century Ottoman Siyāsa Shariyya Texts during the Seventeenth Century

A full discussion of the Ottoman engagement with the siyasa shariyya corpus after the tenth/sixteenth century exceeds the scope of this paper. In what follows below, I will instead wrap up the previous discussion by considering the afterlives of 'Āşlk's Mi'rācüll-eyāle and Cöngì's Risāla fì l-Siyāsa al-shar 'iyya in the core lands of the Ottoman Empire during the eleventh/seventeenth and early twelfth/eighteenth centuries. This discussion is necessary, because certain changes in the social and political dynamics ended up making the siyāsa shariyya literature more relevant to the Ottomans in this period. But there is also another reason for extending the discussion into the eleventh/seventeenth century, and this is the need to speak to a line of scholarship that has persistently argued for the emergence of a distinctive "school of Ibn Taymiyya" in the Ottoman lands during this period. According to this scholarship, the primary carriers of Taymiyyan ideas in the Ottoman lands were the Kadızadelis, who were a group of Sunni revivalist preachers, and their followers, who were

102 Andrews and Kalpakll, The age of beloveds 307, 351-352. 
active in and around Istanbul from the early 1040s/163os until at least the 110os/169os, and who wanted to restore to Ottoman Islam the purity of Islam of the age of the Prophet and his Companions. ${ }^{103}$ As we shall see, nevertheless, the literature actually overestimates both the importance of Taymiyyan ideas for the Kadızadelis and the importance of the Kadızadelis for the spread of Taymiyyan ideas in the core Ottoman lands during the eleventh/seventeenth century. Far more important agents in this regard were people higher up in the imperial administration, who found in the siyassa shar iyya literature possibly some inspiration for, and definitely justification of, the changes they began to introduce into the Ottoman state tradition during the second half of the eleventh/seventeenth century.

The dynamics, nevertheless, were somewhat different in the early decades of the eleventh/seventeenth century, when crisis seemed the order of the day, and when literate men of different walks of life, from military administrators to kadis and from members of the scribal service to preachers, were competing with one another to advise the rulers about how to get out of this crisis. It was also in this context that the preacher and namesake of the Kadizadeli movement, Kaaḍīzāde Meḥmed (d. 1045/1635), hit upon 'Āşıḳ̂s transadaptation of Ibn Taymiyya's al-Siyāsa al-shar'iyya and, after lightly reworking its introduction, submitted it as his own work to Murād IV (r. 1032-1049/162340). ${ }^{104}$

The son of a kadi, and the grandson of a devşirme, Kādīizāde Meḥmed had received his early education from a student of the famous tenth/sixteenthcentury scholar Birgivī Meḥmed Efendi in Bahıkesir but then continued his studies with various other scholars in Istanbul and Cairo. Kādīzāde first took up preaching during his brief stint as a disciple of the Halveti Shaykh Ömer of the Tercüman lodge and persisted in that vocation, also after switching his tariqa affiliation from the Halveti to the Naqshbandi order. ${ }^{105}$ His position as

103 See footnote 4. For broader perspectives on the Kadızadelis, see Zilfi, The Kadizadelis 262-265; Zilfi, Politics of piety 146-159; Baer, Honored; Sariyannis, The Kadızadeli movement; Terzioğlu, Sunna-minded; Tuşalp Atiyas, Sunna-minded trends; Tezcan, The portrait; Shafir, Moral revolutions.

104 For a detailed discussion of the relationship between the two texts, see Terzioğlu, Bir tercüme 264-268. For the correction of the identity of Kạdīizāde Mehmed who claimed the work (and several other works of political advice), see Tezcan, The portrait 215-229.

105 Ibid. 197-215, 241-244; for Kạạīzāde Meḥmed's Naqshbandi affiliation, see also his poem recorded in SK, Ms Yazma Bağışlar 5563, 47a. Until Tezcan's article, the biography of Kădịizāde Mehmed was based largely on the information provided by Katib Çelebi, The balance $132-136$. 
preacher and "advice giver" also allowed Kaadịizāde to cultivate contacts in the Ottoman court. In one of his treatises of advice, the preacher claims that he first wrote a treatise of advice for the grand vizier Kuyucu Murād Paşa (d. 1020/1611) and Ahmed I (r. 1012-1026/1603-17) and was gratified to see his text received by both with great favor. ${ }^{106}$ Later, Kạḍizāde also courted 'Oșmān II (r. 10271031/1618-22) and submitted to him a tract on horses and horsemanship. ${ }^{107}$ Still, none of these engagements can compare to the persistence with which Kaậizāde courted Murād IV, dedicating to him a versified prayer of good wishes (du'anname) on the occasion of his accession to the throne, a versified creed, an anti-Safavid/Kizllbaş tract, and at least five texts of political advice. ${ }^{108}$ One of these five tracts of political advice was Täcürr-resā̉il ve minhācü'l-vesā̉il, an expanded translation of Ibn Taymiyya's al-Siyāsa al-shar'iyya.

Kāḍīzāde Meḥmed's Tācürr-resāill is of particular importance to the debate about the influence of Ibn Taymiyya over the Kadızadelis, as it is the one and only "Kadızadeli" text that we know so far that explicitly references Ibn Taymiyya. The problem is, however, that as mentioned above, this was not actually Kạạīzāde’s own translation but 'Āşık’s. It could be argued that Ḳāḍizāde must have held Ibn Taymiyya in high esteem to want to assume ownership of a translation of the latter's text, but it should also be remembered that the text Kaaḍīzāde appropriated was at least one-third 'Āşlḳ's and incorporated various features that were at odds with the original Taymiyyan vision. There is no indication that Kădīzāde wanted to strip the text of these later additions; in fact, he left all the "supplements" and digressions of "Âşlk intact, and he contented himself with merely changing parts of the introduction to cover up the fact that he was claiming another person's work. Interestingly, in the process, he ended up omitting not only 'Āşılḳ's but also Ibn Taymiyya's name, and instead presented himself ("Shaykh Meḥmed b. Mușțafā known as Kaadīizāde") as the author of the text. ${ }^{109}$ Patient readers could still find out that the text was in part a translation

\footnotetext{
106 Ḳāḍīzāde Meḥmed, Nuṣhü̈l-ḥükkām sebebünn-nizām 2b-3a.

107 Tezcan, The second Ottoman Empire 118-119.

108 Kădịizāde Mehmed, Du'ānāme 114b-118b (written on the occasion of Murād's accession to the throne in 1032/1623); Nazm fì 'ilmi'l-'akầid 4b-67a (composed in 1037/1627-1628); Nașihatnāme 119a-136a; Pādişāh-ı 'ālempenāh ḥażretlerine neșāyiḥ-i keșīre 140a-145a; Nașru'laṣhāb ve kahru's-sebbāb 1a-48b; Nuṣhü'l-hükkām sebebün-nizāam 2b-7oa (composed in 1040/1630-1631); Mesmū'atü'l-nekāyih mecmūatü’n-neșāyih (composed in 1041/1631-1632); Tācür-resāill ve minhācü'l-vesāill. For a critical edition of the Du'ānāme, see Deniz, Kadızade; for a critical edition of Nazmfí 'ilmi'l- 'akẩid, see Karaca, Kadızâde and Büyükkeçeci, Kadızâde; for a modern Turkish publication of another version of the kașíde, see Ürekli, Dördüncü Murad.
}

109 Kạạīzāde Meḥmed, Tācürr-resā̉il 12a. 
of Ibn Taymiyya's al-Siyāsa al-shar'iyya when they got to the part in which 'Āşık announces the end of his translation of the said work and the beginning of the "supplements." 110

Moreover, with a single exception, discussed below, the changes that Kaadīizāde introduced to his version of the text were not any more indicative of a hardcore Taymiyyan than 'Āşık ḳ's transadaptation. For instance, while Kāẹīzāde replaced 'Āşıḳ’s eulogy of Süleymān and Selīm II with a eulogy of Murād IV, the new eulogy also played on number mysticism and the esoteric properties of the sultan's name, just like 'Āşıḳ's. ${ }^{111}$ More remarkable still, Kaaḍīzāde inserted into the text a "letter of invitation" to Islam by an Islamized Alexander the Great. Evidently, Kădịzāde was not a stranger to the eclectic universalism that had characterized the outlook of earlier generations of Ottoman imperial elites. ${ }^{112}$ Lest we think that these are anomalies limited to this text, it is worth pointing out that the other works Kạdịizāde submitted to Murād IV also exhibit a similar diversity of sources of inspiration, from Quranic verses to Sufi poetry to excerpts from a Turkish rendition of the pseudo-Aristotelian Kitāb Sirr al-asrār ${ }^{113}$ It is only in the texts that he authored for ordinary Muslims that Kâdịizāde restricted himself to verses from the Quran and excerpts from jurisprudential texts. ${ }^{114}$ It would seem that the socially bifurcated cultural codes of early modern Ottoman polite society also held for this early eleventh/seventeenth-century preacher: he spoke to the elites in one discursive register and to the commoners in another.

In short, Kạạizzāde Mehmed was not quite the uncompromisingly "puritanical," "antisyncretistic," and "anti-elitist" Muslim reformist that modern scholars have imagined him to be; nor was he any more Taymiyyan in his disposition than, say, 'Āşsk had been. This having been said, he did insert into his revised

\footnotetext{
110 Ibid. 121a.

111 Ibid. 11a-b.

112 Ibid. 8a-b. Even though the Ottoman fascination with Alexander the Great has been said to be more a phenomenon of the ninth/fifteenth and early tenth/sixteenth centuries, there are also other eleventh/seventeenth-century Ottoman texts featuring Alexander as an ideal ruler. For explorations of the Ottoman Alexander corpus, listed in the order of their chronological focus, see Kastritsis, The Alexander romance; Beaudoen, Mirrors; Krstić, Of translation 134-136; Şen, The dream; on the Ottoman versions of the book of advice supposed to have been written by Aristotle for Alexander, see Yllmaz, Caliphate $63-64$.

113 For excerpts from the pseudo-Aristotelian Kitāb Sırr al-asrār, see Kāạīzāde Mehmmed, Mesmū'atü'l-nekāyih 8b-12b.

114 See, for instance, Kāạīzāde Mehmed, Risāle-i Kẫūizāde Mehmed 94b-103a; Risāle-i İmān ve İslām 103b-107b; Risāle-i Șalāt 44b-47a. For an analysis of Ḳāḍizāde Meḥmed's religiolegal writings aimed at a wider audience, see Tezcan, A canon of disenchantment.
} 
version of the transadaptation one passage that would be of interest to scholars looking for Taymiyyan influences in the Kadizadeli milieu. The passage in question discusses the different types of idolatry (şirk) and is taken from Ibn Qayyim al-Jawziyya's Ighāthat al-lahfān min mașāìd al-shayțān (Rescuing the distressed from the snares of the devil). Interestingly, Kădịizāde does not reveal his source but simply says that he took the text from works of kelām. He does, however, cite the same passage on idolatry in another work of political advice, where he gives the correct title of the source but misattributes it to another Hanbali scholar, Abū 'l-Faraj Ibn al-Jawzī (d. 597/1201).115

The reference to Ibn Qayyim al-Jawziyya's Ighäthat al-lahfān is noteworthy, because this Hanbali writer was the most important student of Ibn Taymiyya and because modern scholars who have been convinced of the Kadizadelis' Taymiyyan convictions have rested their case in recent years mainly on the fact that the Ottoman writers who were or who fit the profile of Kadızadelis cited Ibn Qayyim al-Jawziyya, and especially his Ighāthat al-lahfān. ${ }^{116}$ One of these scholars, Sheikh, has further argued that the Kadizadelis were far more immersed in the writings of Ibn Taymiyya than they let on, but that because of the controversy surrounding the latter's name, they preferred to give reference to his less controversial student, Ibn Qayyim al-Jawziyya, instead. ${ }^{117}$ This view, however, is rather speculative and is open to critique on several grounds. First, while Sheikh has identified in the works of two key thinkers who inspired the Kadızadeli movement, Birgivī and Aḥmed Rūmī el-Aḳhiṣārī (d. ca. 1041/1632), two passages that seem to be taken from Ibn Taymiyya's Iqtidā l-șirăt al-mustaqīm (The necessity of the straight path), ${ }^{118}$ this would hardly suffice to identify these otherwise solidly Hanafi-Maturidi scholars as crypto-Taymiyyans. ${ }^{119}$ Secondly, the supposition that Ibn Taymiyya was considered too controversial a name to be explicitly mentioned in the Rumi context also needs to be qualified: it is true that some works and ideas of Ibn

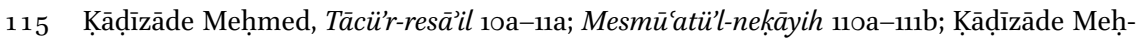
med also praises the same work in a letter he wrote to the şeyhüll-islām Hocazāde Mehmed, see Tezcan, The portrait 207, 214.

116 Michot, Introduction; Sheikh, Ottoman puritanism; Sheikh, Taymiyyan influences; Sheikh, Taymiyyan tașawwuf.

117 Sheikh, Taymiyyan influences 17-19; Ottoman puritanism 128-131.

118 Sheikh, Taymiyyan influences 12-17; Ottoman puritanism 118-128.

119 For the relevant scholarship, see footnote 6. Other than the passages identified by Sheikh, the arguments that Birgivi was a crypto-Taymiyyan have been based largely on the misattribution to him of works that were authored by Aḳ̣ișāīi for the correction of these misattributions and a discussion of their implications, see Kayl, A critical study $5^{2-81}$, 119-125, 137-139, 141-142. 
Taymiyya, such as his rejection of tomb visitations, were considered by some (perhaps many) Ottoman scholars to be deeply objectionable, but some other works and ideas were not, as evidenced by the translation(s) of his al-Siyāsa al-shar iyya into Turkish. ${ }^{120}$ It could be argued that the Kadizadelis felt more vulnerable than other more "mainstream" Ottoman scholars when citing Ibn Taymiyya, because they, too, targeted such popular practices as tomb visitations as bid'ats, but it has to be said that even in the highly polarized environment of eleventh/seventeenth-century Istanbul, where their critics referred to the Kadızadelis regularly as "fanatics" (muta'așșibin), "hypocrites" (mürǟ̄), and "deniers" (münkirin), no one associated them with Ibn Taymiyya, except perhaps indirectly in the context of the debates on tomb visitations and the congregational performance of supererogatory prayers. ${ }^{121}$ Thirdly, Sheikh's claim that the Kadızadelis may have cited Ibn Qayyim al-Jawziyya as a safer choice than his teacher is based on the assumption that the writings of the two men were otherwise equally well known to eleventh/seventeenth-century Ottoman scholars. This was not actually the case, however, since as Caterina Bori has recently shown, even an unusually well-read bibliophile like Kātib Çelebi (d. 1067/1657) was far more familiar with the contents of the works of Ibn Qayyim al-Jawziyya than with those of Ibn Taymiyya. ${ }^{122}$

In short, even if the Kadıadelis were more familiar with Ibn Taymiyya than they let on, the evidence at hand does not support the view that they represented on the whole a "school of Ibn Taymiyya" or even a distinctively "Taymiyyan" subcurrent of Hanafi-Maturidi Islam in the lands of Rum. Neither is it possible to say that they played an especially significant role in spreading

120 It seems that Sheikh is not aware of the existence of either the Mirācü'l-eyāle or Täcürrresā'il, or for that matter, the Risāla fì l-Siyāsa al-shar'iyya, for he lists the "theology of liberation" that he finds in Ibn Taymiyya's al-Siyāsa al-shar'iyya among the factors that would have made the Hanbali scholar an anathema among the Ottomans; see Sheikh, Ottoman puritanism 129-130.

121 For references to Ibn Taymiyya in the context of the eleventh/seventeenth-century Ottoman debate on tomb visitations, see 'Abdü'l-mecīd Sivāsī, Dürer-i 'akāì 81a-82a; Katib Çelebi, The balance 93. Of these commentators, Sivāsī (d. 1049/1639) was a learned Halveti shaykh, an ardent supporter of Ottoman Sunnism, and, in the last decade of his life, a vocal adversary of Kāḍizāande Mehmed, while Kātib Çelebi stood equidistant to both the Kadızadelis and their critics. Notwithstanding their differences, both of these writers agreed that Ibn Taymiyya had been an indisputably errant figure and had erred also in taking a radical stance against tomb visitations. Both also discounted his views by noting how he had been branded an unbeliever "by the generality of the ulema of Egypt" and died in jail. It was in a very similar manner that the Celveti Sufi master İsmaîl Ḥaḳkī Bursevī (d. 1137/1725) brought up the name of Ibn Taymiyya to delegitimate the attack against the Regāib and Berāt prayers in his own time. On this, see Cengiz, İsmail Hakkı Bursevî 135.

122 Bori, Ibn Taymiyya (14th to 17th century) 115-117; see also 112-115 for observations about knowledge of Ibn Taymiyya in other parts of the Ottoman Empire in this period. 
the knowledge of Ibn Taymiyya's al-Siyāsa al-shar'iyya in the eleventh/seventeenth century. Today we know of only three manuscript copies of Kaadịizāde Mehmed's Tācürr-resāil anywhere, as opposed to ten manuscript copies of 'Āşıł's Mi'rācül-eyāle in Turkey alone. ${ }^{123}$ It was also only the latter version that was mentioned in Kātib Çelebi's bibliographical compendium Kashf alzunūn. ${ }^{124}$ It is telling, too, that Tācür-resā̉il was not copied together with other, more popular, works that were written by Kạḍīzāde Meḥmed for the benefit of Muslims in general. It seems that both versions of the translation ultimately catered to high-ranking members of the imperial administration than to either a more exclusively scholarly or a more popular readership.

Much the same observations can be made about the circulation of the Arabic originals of Ibn Taymiyya's al-Siyāsa al-shariyya in Istanbul in this period. Currently, Istanbul's manuscript libraries contain twelve manuscript copies of the original Arabic epistle, roughly equal to the total number of copies of both versions of the Turkish transadaptations in the same collections. Judging by the codicological evidence, most, if not all, of these copies of the Arabic original had come into the possession of Istanbuli readers either in the late eleventh/seventeenth or in the early twelfth/eighteenth centuries. In fact, there may even have been something of a competition among the top-ranking Ottoman grandees to obtain precious copies of this work in this period. The şeyhü'l-islām Feyżullāh Efendi (d. 1115/1703), who was a former student and sonin-law of the "third-generation Kadızadeli leader" and preacher Vānī Meḥmed Efendi (d. 1096/1685), as well as one of the most well-read, most politically active (and most controversial) scholars of his time, evidently cared enough about the work to obtain an early and precious copy, one that had been copied in $850 / 1446-1447$ to be presented to a high-placed Mamluk official. ${ }^{125}$ The grand

123 Kạạīzāde Meḥmed, Tācürr-resā̉il, sk, Ms Hacı Mahmud Efendi 1926;Topkapı Sarayı Müzesi Kütüphanesi (hereafter тsмк), Ms Hazine 371/1, 1a-48a; Staatsbibliothek zu Berlin, ms Diez A quart 46. This last copy bears a reader's note dated 1047/1637-1638 (ia), indicating that the work must have been copied before that date. The other copies are undated. Cf. 'Āşık, Mírācü'l-eyāle тSMк, MS Revan 1610 (copied in 1005/1596-1597); SK, MS Reisülküttab 1006 (copied in 1008/16oo); Nuruosmaniye MS 2315 (copied in 1009/16oo); SK, MS Esad Efendi 1901 (copied in 1011/16o2); SK, MS Esad Efendi 1803/1, 1b-94b (copied in 1054/1644); TSMK, MS Hazine 1768/1, 1b-117a (copied in 1088/1677-1678); Milli Kütüphane, MS A. 8112; SK, MS Şehid Ali Paşa 1556; sK, MS Çelebi Abdullah Efendi 51/2, 38b-217b; Yapı Kredi Sermet Çifter Araştırma Kütüphanesi, Ms Türkçe Yazmalar 466/1.

124 Katib Çelebi, Keșfel-zünun ii, 1011.

125 For the copy, see Ibn Taymiyya, al-Siyāsa al-shar iyya, Millet Kütüphanesi, Ms Feyzullah 129 o (copied by 'Alī b. Süleymān in 850/1446-1447); the text is also listed in Feyżu'llāh's endowment deed; Feyzullah Efendi Vakfiyesi, Millet Kütüphanesi, Ms Feyzullah 2189, 223a; on Feyżu'llāh, see Meservey, Feyzullah; Abou-el-haj, The 1703 rebellion; Nizri, Ottoman high politics, esp. ch. 1 . 
vizier Şehīd 'Alī Paşa (d. 1128/1716), who was also a known bibliophile, but who had nothing to do with the Kadızadelis and was in fact a Sufi sympathizer and even reputed to be a Bayrami-Melami kuțb, also owned three copies of the work, one of which had been copied very early, in $780 / 1378-1379 .{ }^{126}$ It is evident that the interest in the tract (and its earliest copies) continued at the highest levels of the imperial hierarchy also in the twelfth/eighteenth century. We find two other Mamluk-era copies of the work in the library of Ahmed III (r. 1115-1143/1703-30), dated $766 / 1363$ and $797 / 1395$, and four copies of the work in the library established by Mahmūd I (r. 1143-1168/1730-54); two of the copies in Mahmūd's library also dated from the Mamluk era, from 744/1343 and 893/1488 specifically. ${ }^{127}$ The head of the scribal bureaucracy, Re'îsül-küttāb Mușțafā Efendi (d. 1162/1749), too, owned a copy, which bears the endowment date of $1154 / 1741-1742 .{ }^{128}$

Considering that all these individuals were known bibliophiles and founders of waqf libraries, it is reasonable to think that their demand for precious copies of al-Siyāsa al-shar 'iyya was fueled in part by their bibliophilia. ${ }^{129}$ But it cannot have been just the antiquarian appeal of the Mamluk-era Siyāsa al-shariyya copies that recommended the text to the Ottoman readers. The latter must also have been interested in the subject matter, siyāsa shariyya. What suggests this is the even greater popularity of Dede Cöngìs Risāla fíl-Siyāsa al-shar iyya starting slightly earlier. In fact, this decidedly more recent epistle dwarfs Ibn Taymiyya's famous work in terms of its popularity with eleventh/seventeenthand twelfth/eighteenth-century readers in the Ottoman capital. My prelimi-

126 Ibn Taymiyya, al-Siyāsa al-shar iyya, SK, MS Şehid Ali Paşa 1553/1, 1-76 (copied in 780/13781379); SK, MS Şehid Ali Paşa 1544 (copied by Muṣliḥu'd-dīn Ebū'l-hayr Aḥmed in Istanbul in Ż̀'l-ḥicce 1109/1698); sK MS Şehid Ali Paşa 1543 (previously owned by a certain Ḥüseyin in 1011/1602-16o3). On the first of these manuscripts, see Bori, One or two versions; on Şehīd 'Alī Pasha, see Özcan, Şehid Ali Paşa; Gölpınarl, Melâmîlik 165-166.

127 For manuscripts of Ibn Taymiyya's al-Siyāsa al-shariyya in the collection of Ahmed III, see TSMK, MS Ahmet III 1118 (copied in 797/1395) and TSMK, MS Ahmet III 117 (copied in 766/1363), and Karatay, Topkapı Sarayı Müzesi Kütüphanesi Arapça yazmalar ii, \#466o, \#4661. For manuscripts of the same work in the collection of Mahmūd I, see SK, MS Ayasofya $2886 / 1$ (copied in 893/1488); sk, MS Ayasofya 2887 (copied in 999/1591); sK, MS Ayasofya 2888; 2889 (copied in 744/1343).

128 Ibn Taymiyya, al-Siyāsa al-shar'iyya, sk, ms Reisülküttap 528. This seems to be a twelfth/ eighteenth-century manuscript. Other manuscript copies of the work preserved in Istanbul libraries are Sк, MS Yahya Tevfik 270, which is undated but has an owner's note dated 1186/1772-1773 and Bayezid, MS 1987, which was inaccessible at the time of research for this paper.

129 Erünsal, Osmanlılarda kütüphaneler; Sezer, The architecture of bibliophilia. 
nary research in the database of the Süleymaniye library in Istanbul in the summer of 2019 has revealed over 6o manuscript copies of Cöngìs text, as compared to 12 manuscript copies of Ibn Taymiyya's al-Siyāsa al-shar iyya. ${ }^{130}$ Of course, Cöngi's text did not just circulate in Istanbul but also in other intellectual and administrative centers in the Ottoman lands, including the Arab provinces, but my point is that the text had a particular relevance for the Turcophone Rumi ruling cadres. ${ }^{131}$ This is also indicated by the fact that the Risāla fi l-Siyāsa alshar iyy a was translated into Turkish no less than three times between the late eleventh/seventeenth and early thirteenth/nineteenth centuries. The earliest of these was a rather faithful translation made by Sebzī Seyyid Meḥmed Efendi (d. 1091/1680) sometime in the second half of the eleventh/seventeenth century and represented in Süleymaniye's database with some ten manuscript copies, the earliest of which dates from 1121/1709. ${ }^{132}$

What is interesting is that Dede Cöngì's text received all this attention after having hardly received any during the first 80 to 100 years of its existence. The earliest known extant manuscript copy of the work is dated 1054/1644-1645, followed by two other copies, dated 1067/1657 and 1069/1658.133 These were the years when Cöngī’s famous progeny, Minkāāizāde Yahyyā (d. 1088/1678), was climbing up the ranks of the Ottoman learned hierarchy to become eventually one of the longest serving şeyhül-isläms of the eleventh/seventeenth century. This raises the possibility that the text was brought to the attention of the wider public by either Minkārīzāde or someone else who knew of the family connection between the two men. This possibility is also supported by the fact

\footnotetext{
130 For a partial list, see Bibliography.

131 For some copies of the text preserved in libraries in such cities as Cairo and Riyad, see Dede Efendi, al-Siyāsa al-shariyya 5-20.

132 For the Latinized transcription of Sebzī Efendi's translation, see Açlk, Dede Cöngî'nin; for manuscript copies, see MS SK, Hacı Mahmud Efendi 1914; Ms Millet K, A.E. Şeriyye 398 (copied in 1199/1784-1785); Ms sK, Hüsrev Paşa 639/4, 195-244; Ms Milli Ktp, A 9124; MS Nuruosmaniye, 203/2; Ms Beyazit Devlet K, Bayezit 479o; Ms Beyazit Devlet K, Bayezit 489 o (copied in 115o/1737-1738); MS SK, Hacı Mahmud Efendi 1914; MS Nuruosmaniye 4982/1, 1b-35b (copied in 1121/1709); Ms Nuruosmaniye 4892/3, 71-105. For the translations made by İsmāîil Müfĩd Efendi (d. 1217/1802) and by the şeyhüll-islām Meşrebzāde 'Ārif Efendi (d. 1275/1858), see Akgündüz (ed.), Osmanlı kanunnameleri iv, 122-212; Erten, Tercüme-i Siyâsetnâme'nin tahlîli and Erel, Dede Cöngi's.

133 Dede Cöngī, Siyāsetnāme/Risāla fì l-Siyāsa al-shar'iyya, sK, MS Şehid Ali Paşa 2725/55, 254-262 (copied in Żìl-ḳa'de 1054/December 1644-January 1645); sK, Ms Ragip Paşa 639/3, 13ob-142a (copied in 1067/1656-1657); Diyarbakır İl Halk Kütüphanesi, MS 104/2, 24b37a (copied in 1069/1658); SK, MS Esad Efendi 924/4, 166b-187a (copied in 1083/16721673).
} 
that the text's first Turkish translator, Sebzī, introduces Cöngī as "the ancestor of Minkāāizāde" (cedd-i Minḳārīzāde) in the preface to his translation of the text. ${ }^{134}$

Whatever the role of Minḳārīzāde was behind the rise of Cöngīs Risāla fì lsiyassa al-shar'iyya from obscurity to fame, there was certainly a broader context to the interest that high-level Ottomans took in the siyassa shar'iyya literature, and more broadly, juristic works on rulership, in this period. From the appointment of Köprülü Mehmed as grand vizier (1066/1656) to the Ottoman defeat at Vienna (1094/1683), a succession of viziers from the Köprülü household worked hard to restore the control of the imperial government over the myriad restless power groups, both in the capital and in the provinces, and while doing so, they leaned heavily on religiously inspired measures of social disciplining. ${ }^{135}$ It was also in this period that they introduced to the recently conquered island of Crete (1081/1670) and the resubdued Basra (1080/1669) a system of land tenure and taxation that was decidedly more "Islamic" than earlier Ottoman practices and that allowed for private ownership of land as well as heavier rates of taxation. ${ }^{136}$ Significantly, Ottoman experimentations with "shar i governance"

134 Until now, the main source of the claim about the family relationship between the two men was the preface to the first Turkish translation of Cöngī's Risāla fíl-Siyāsa al-shar'iyya; for the reference, see Açı, Dede Cöngînnin 8. A recent discovery by Özgün Deniz Yoldaşlar, who is currently writing his $\mathrm{PhD}$ thesis on Minḳārīzāde, has thrown up new evidence in strong support of this conclusion. The evidence in question is a note made by Minḳārīzāde Yahyaā in his copy of Dede Cöngī’s supercommentary on Taftāzānì's commentary on 'Izz aldīn al-Zanjānī's al-Izzîfi-l-tașrīf, and reads: "This is the supercommentary of the maternal ancestor of this poor slave on the commentary on Zanjānī by Sa'dü'l-mille ve'd-dīn and I am the sinner, Yahyā, son of 'Ömer (May He forgive both)." See Dede Cöngī, Hāshiyya 'alā sharh al-Izzīfi-l-tașrîf, sk, Ms Murad Molla 1734, 1a. I thank Yoldaşlar for allowing me to share this important finding.

135 Among the measures of "social disciplining" deployed in this period were the bans on wine taverns, coffeehouses, and alehouses, and even on the trade in coffee and tobacco; the prohibition of the Sufi devrān and the Mevlevi sema $\bar{a}$, and the banishment of Sufi shaykhs who did not abide by this prohibition. The Köprülüs also revived the early eleventh/seventeenth-century project of reclaiming Eminönü for the Muslims and pushing the Jews and Christians residing there to the outer skirts of the city. For differing perspectives on these policies, see Baer, Honored; Thys-Şenocak, The Yeni Valide complex; Ylldız, 166o. For an aborted attempt to reform the religious beliefs and practices of Ottoman Muslims circa 1113/1702, see Abou-el-Haj, Formation 51-52, 91-97.

${ }_{13} 6$ For differing perspectives on the land tenure and taxation system implemented in Crete, see Veinstein, On the çiftlik debate; Veinstein, Le législateur ottoman; Veinstein, Les règlements fiscaux; Greene, An Islamic experiment; Greene, A shared world 25-29; Kermeli, Caught in between faith and cash; Kolovos, Beyond "classical" Ottoman defterology; on the system implemented in Basra, see Khoury, Administrative practice. 
continued also in the late eleventh/seventeenth and early twelfth/eighteenth centuries. The Ottoman poll-tax reforms and the short-lived attempt to abolish price ceilings (narh), both of which were instituted by the grand vizier Köprülüzāde Mușțafā in 1102/1691, and the abolition of some taxes and fines as bid'ats in the kānūnnāme of Midilli (Mytileni) in 1121/1709 can be mentioned as some pertinent examples. ${ }^{137}$ As Ekin Tuşalp Atiyas has pointed out, the Ottoman officials did not name specific texts but rather evoked the authority of either "the sharia" or "the books of Islamic jurisprudence" when they wanted to explain why they were breaking ways with some of the old Ottoman state traditions. ${ }^{138}$

A new disinclination to use the word kānūn on the part of the Ottoman imperial administration at the turn of the eleventh/seventeenth century went hand in hand with this development. This trend culminated in the famous decree of Muștafā II in 1108/1696 that all Ottoman imperial orders from that point on reference only "the noble sharia" and not "couple the [terms] noble sharia and kānūn."139 Of course, not all Ottoman men of letters and statesmen shared this aversion to the use of the word kannūn, as indicated by the continued references to kānūn in Ottoman political and historical literature throughout the eleventh/seventeenth century. ${ }^{140}$ Nor was the decree of $1108 / 1696$ the end of the legislative functions of the Ottoman sultans. Quite to the contrary, in the twelfth/eighteenth century, the Ottoman rulers continued to make laws just as - if not more vigorously - and Muslim jurists referenced royal edicts even to a greater degree than before in their juridical rulings. ${ }^{141}$ However, now, the Ottoman rulers justified their lawmaking with reference to shar $i$ norms first and foremost, and only secondarily with reference to their cumulative dynastic

137 On the 1102/1691 reforms, see Sariyannis, Notes on the Ottoman poll-tax reforms; Tuşalp Atiyas, The Sunna-minded trend $272-276$. On Köprülüzāde Muștafā's justification of the reforms on shar'ī grounds, see Defterdar Sarı Mehmed Paşa, Zübde-ivekayiât 387-389. On the kānūnnāme of Mytileni (Midilli), see the studies cited in footnote 136.

138 Tuşalp Atiyas, The sunna-minded trend, esp. 238-239, 265-272.

139 Heyd, Studies in old Ottoman, 154-155.

140 Abou-El-Haj, Power and social order; Tezcan, The second Ottoman Empire esp. 49-58; Darling, A history of social justice, 146-148; Ferguson, The proper order, ch. 6; Sariyannis, A history, chs. 4-8.

141 On the continued relevance of kānūn during the twelfth/eighteenth century, see Tuğ, Politics of honor $55^{-67}$; on the progressive incorporation of royal edicts into the fatwa texts of Ottoman ulama, see Ayoub, The sulțān says. On the role of state authorities in law enforcement and social and moral regulation in the twelfth/eighteenth century, see also Ergene, Local court; Semerdjian, "Off the straight path"; Zarinebaf, Crime and punishment; Zilfi, Women and slavery; Aykan, Rendre le justice; Baldwin, Islamic law; Başaran, Selim III. 
traditions. It was precisely this shift, I would argue, that also explains the main attraction of Cöngìs modest treatise on siyāsa shar'iyya to the later Ottomans. Cöngī had legitimated the Ottoman kānūn under the rubric of the Mamluk siyassa and without so much as a reference to the Ottoman dynasty, styling it as the kind of siyāsa that serves "shar' $\bar{\imath}$ ends" and safeguards public order. Even if Cöngìs original concern had been to intervene in a debate centered in the empire's newly annexed provinces of Egypt and Syria during the tenth/sixteenth century, his solution to that debate turned out to be just as relevant to the needs of the empire's overwhelmingly Rumi ruling elites in the following century. It seems that this particular definition of kānūn, as ruler's law in service of the divine law, which could be adjusted to the changing needs of the time, rather than as accretive dynastic custom, had won the day.

\section{Acknowledgments}

An earlier version of a section of this article was first published in Turkish in Terzioğlu, Bir tercüme 247-275. The research for the present article was supported by the European Research Council under the European Union's Seventh Framework Programme (FP/2015-202O)/ERC Grant Agreement 648498, "The fashioning of a Sunni orthodoxy and the entangled histories of confessionbuilding in the Ottoman Empire, 15th-17th centuries." Tijana Krstić, Guy Burak, Baki Tezcan, Başak Tuğ, Ahmet Kaylı, Özgün Deniz Yoldaşlar, Arif Erbil, A. Vahdi Kanatsız, and Evren Sünnetçioğlu gave valuable feedback on this paper. I am grateful to them all. Naturally, I claim sole responsibility for all errors that remain.

\section{Bibliography}

\section{Primary Sources}

'Abdü'l-mecīd Sivāsī, Dürer-i 'akâảid, Süleymaniye Kütüphanesi, Ms Mihrişah 3oo/1, 1a$116 \mathrm{~b}$.

Akgündüz, A. (ed.) Osmanlı kanunnâmeleri ve hukuki tahlilleri, 9 vols., Istanbul 1992.

Ali b. Bâlî, El-Ikdül-manzûm fì zikri efâzili'r-Rûm: Ali b. Bâlînin Şakâik Zeyli, ed. S. Donuk, Istanbul 2018.

'Āşık Çelebi, Dhayl al-shaqāì al-nu'māniyya fì 'ulamä̀i dawlati'l-uthmāniyya, ed. 'A. Rāziq Barakāt, Cairo 2007.

Âşık Çelebi, Meşấirü’ş-şu'arâ: İnceleme—metin, ed. F. Kılıç, Istanbul 2010. 
‘Āşılk Çelebi, Mirrācü'l-eyāle ve minhācü'l-'adāle.

1) Milli Kütüphane, Ms A. 8112.

2) Süleymaniye Kütüphanesi, Ms Şehid Ali Paşa 1556

3) Süleymaniye Kütüphanesi, Ms Reisülküttab 1006

4) Süleymaniye Kütüphanesi, Ms Esad Efendi 1901

5) Süleymaniye Kütüphanesi, Ms Esad Efendi 18o3/1, 1b-94b

6) Süleymaniye Kütüphanesi, Ms Çelebi Abdullah Efendi 51/2, 38b-217b

7) Nuruosmaniye Kütüphanesi, Ms 2315

8) Topkapı Sarayı Müzesi Kütüphanesi, ms Hazine 1768/1, 1b-117a

9) Topkapı Sarayı Müzesi Kütüphanesi, Ms Revan 1610

10) Yapı Kredi Sermet Çifter Araştırma Kütüphanesi, ms Türkçe Yazmalar 466/1

Âşık Çelebi, Mirrâcü'l-eyâle ve minhâcül-'adâle: Âşık Çelebinin siyâsetnâmesi, ed. U.

Onuş et al., Istanbul 2018.

Atâyî, Nevîzâde, Hadâikü’l-hakâik fî̀ tekmiletişs-şakâik, ed. S. Donuk, 2 vols., Istanbul 2017.

Cengiz, M., İsmail Hakkı Bursevî̀nin Tuhfe-i hasekiye'sinin birinci bölümü (Metin ve tahlil), MA thesis, Marmara Üniversitesi, 2007.

Dede Cöngī, Hâashiyya 'alā sharh al-İzzīf lı-l-tașrīf, Süleymaniye Kütüphanesi, Ms Murad Molla 1734 .

Dede Cöngī, Siyāsetnāme/Risāla fì l-Siyāsa al-shar iyya (Partial list given only).

1) Süleymaniye Kütüphanesi, Ms Ağa Efendi Tanacan 41/8, 9ob-107a

2) Süleymaniye Kütüphanesi, Ms Esad Efendi 924/4, 166b-187a

3) Süleymaniye Kütüphanesi, Ms Esad Efendi 3610/6, 156b-164b

4) Süleymaniye Kütüphanesi, Ms Şehid Ali Paşa 2725/55, 254-262

5) Süleymaniye Kütüphanesi, Ms Ragip Paşa 639/3, 13ob-142a

6) Diyarbakır İl Halk Kütüphanesi Ms 104/2, 24b-37a

7) Süleymaniye Kütüphanesi, Ms Reşid Efendi 182/8

8) Süleymaniye Kütüphanesi, Ms Esad Efendi 3754/1, 1b-17a

Dede Cöngī, Şerî̀ siyaset, ed. A.C. Köksal, Istanbul 2019.

Dede Cöngī, Risāla fì amwāli bayti-l-māl wa-aqsāmihā wa-ahkāmihā wa-maṣārifihā, Süleymaniye Kütüphanesi, Ms Esad Efendi 356o, 1b-2oa.

Dede Efendi, al-Siyāsa al-shar'iyya, ed. F. 'Abd al-Mun'im, Alexandria n.d.

Defterdar Sarı Mehmed Paşa, Zübde-i vekayiât, ed. A. Özcan, Ankara 1995.

[Ebū's-su'ūd], Şeyhülislâm Ebussu'ûd Efendi'nin fetvalarına göre Kanunî devrinde Osmanlı hayatı: Fetâvâ-yı Ebussu'ûd Efendi, ed. M.E. Düzdağ, Istanbul 1998.

Ferīdūn Bey, Münşe'ātü's-selāțīn, Süleymaniye Kütüphanesi, Ms Ragıp Paşa $15^{21 .}$ Ibn Nujaym, Risāla fíl-Siyāsa al-shariiyya.

1) Süleymaniye Kütüphanesi, Ms Carullah 2120/2, 39b-53b

2) Süleymaniye Kütüphanesi, Ms Hacı Mahmud Efendi 1097/1, 1a-14a

3) Süleymaniye Kütüphanesi, Ms Hüsrev Paşa 758/3, 29a-38a 
4) Süleymaniye Kütüphanesi, Ms Laleli 961/4, 411b-423b

5) Süleymaniye Kütüphanesi, Ms Reşid Efendi 1027/13, 128a-143a

Ibn Taymiyya, al-Siyāsa al-shar ‘yyya fi iṣlāḥ al-rā‘̄wa-al-ra ìyya, ed. 'A. al-Gharīb, Dammam 2000.

Ibn Taymiyya, al-Siyāsa al-shar'iyya fì ișlāḥ al-rāì wa-al-ra ìyya.

1) Millet Kütüphanesi, Ms Feyzullah 1290

2) Süleymaniye Kütüphanesi, Ms Şehid Ali Paşa 1553/1, 1-76

3) Süleymaniye Kütüphanesi, Ms Şehid Ali Paşa 1543

4) Süleymaniye Kütüphanesi, Ms Şehid Ali Paşa 1544

5) Topkapı Sarayı Müzesi Kütüphanesi, ms Ahmed 1118

6) Topkapı Sarayı Müzesi Kütüphanesi, Ms Ahmed 117

7) Süleymaniye Kütüphanesi, Ms Ayasofya 2886/1

8) Süleymaniye Kütüphanesi, Ms Ayasofya 2887

9) Süleymaniye Kütüphanesi, Ms Ayasofya 2888

10) Süleymaniye Kütüphanesi, Ms Ayasofya 2889

11) Süleymaniye Kütüphanesi, Ms Reisülküttab 528

12) Süleymaniye Kütüphanesi, Ms Yahya Tevfik 270

Ibn Taymiyya, Ibn Taimiyya on public and private law in Islam, or public policy in Islamic jurisprudence, trans. O.A. Farrukh, Beirut 1966.

Kāạīzāde Meḥmed, Dưānāme, Topkapı Sarayı Müzesi Kütüphanesi, Ms Emanet Hazine 1739/8, 114b-118b.

Kāạīzāde Meḥmed, Mesmū'atü'l-neḳāyih mecmū'atü’n-neșāyih, Süleymaniye Kütüphanesi, Ms Hüsrev Paşa 629.

Kạạīzāde Meḥmed, Nașịhatnāme, Topkapı Sarayı Müzesi Kütüphanesi, Ms Emanet Hazine 1739/9, 119a-136a.

Kāạīzāde Meḥmed, Nașru'l-aṣhāa b ḳahru's-sebbāb, İstanbul Üniversitesi Nadir Eserler Kütüphanesi, ms Türkçe Yazmalar 3529/1, 1a-48b.

Kāạīzāde Meḥmed, Naẓm fì 'ilmi'l-akâ̄id, Topkapı Sarayı Müzesi Kütüphanesi, MS Emanet Hazine 1739/1, 4b-67a.

Kạḍīzāde Meḥmed, Nuṣ̣ü̉l-hükkām sebebü’n-nizām, İstanbul Üniversitesi Nadir Eserler Kütüphanesi, ms Türkçe Yazmalar 6966/1, 2b-70a.

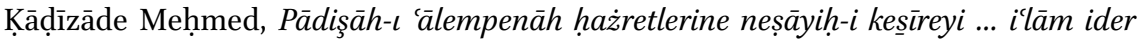
bir ḳașide, Topkapı Sarayı Müzesi Kütüphanesi, Ms Emanet Hazine 1739/11, 140a145 a.

Kạạīzāde Meḥmed, Risāle-i İmān ve İslām, Topkapı Sarayı Müzesi Kütüphanesi, MS Emanet Hazine 1739, 103b-107b.

Kāạīzāde Meḥmed, Risāle-i Kāḍ̂̀zāde Meḥmed, Topkapı Sarayı Müzesi Kütüphanesi, Ms Emanet Hazine 1739, 94b-103a.

Kāọīzāde Meḥmed, Risāle-i Ṣalāṭ, Süleymaniye Kütüphanesi, Ms Yazma Bağışlar 5563, $44 \mathrm{~b}-47 \mathrm{a}$. 
Kạḍīzāde Meḥmed, Tācürr-resā’il ve minhācü'l-vesāil.

1) Süleymaniye Kütüphanesi, Ms Hacı Mahmud Efendi 1926

2) Topkapı Sarayı Müzesi Kütüphanesi, Ms Hazine 371/1, 1a-48a

3) Staatsbibliothek zu Berlin, Ms Diez A quart 46

El-Kâfiyeci, Muhyiddin, Seyfü'l-mülûk, Seyfü'l-kudât: Kâfiyeci'nin siyâsetnâmeleri, ed. N. Okuyucu, Istanbul 2018.

Katib Çelebi, The balance of truth, trans. G.L. Lewis, London 1957.

Katib Çelebi, Keşf el-zünun, eds. Ş. Yaltkaya and K.R. Bilge, 2 vols., Istanbul 1941.

Ta līịīzāde, Ta 'līḳ̂-zāde’s Şehnāme-i hümāyūn: A history of the Ottoman campaign into Hungary, 1593-1594, ed. and trans. C. Woodhead, (IU 82), Berlin 1983.

Ṭarābulusī, A., Mu ìn al-ḥukkām, Ann Arbor, University of Michigan, Special Collections Library, Isl. Ms. $5^{8}$ (Accessible online via the Hathi Trust digital library, http://hdl .handle.net/2027/mdp.39015079105733).

Taşköprülüzâde, A., eş-Şakâ'iḳ'n-nu'mâniye fî ulemâi'd-devleti Osmâniyye, ed. M. Hekimoğlu, Istanbul 2019.

Tursun Bey, Târîh-i Ebü'l-Feth, ed. M. Tulum, Istanbul 1977.

Yücel, Y. (ed.), Osmanlı devlet teşkilâtına dair kaynaklar: Kitâb-ı Müstetâb, Kitabu Mesâlihi'l-müslimîn ve menâfi i’l-mü'minîn, Hırzü'l-mülûk, Ankara 1988.

\section{Secondary Sources}

Abou-El-Haj, R.A., Formation of the modern state: The Ottoman Empire, sixteenth to eighteenth centuries, Albany 1991.

Abou-El-Haj, R.A., Power and social order: The uses of the kanun, in D. Preziosi and R.A. Abou-El-Haj (eds.), The Ottoman city and its parts: Urban structure and social order, New Rochelle and Caratzas 1991, 77-99.

Abou-El-Haj, R.A., The 1703 rebellion and the structure of Ottoman politics, Leiden 1984.

Acun, F., Osmanlı İmparatorluğu'nda gayrımüslim din adamlarına verilen imtiyazlar: 16. yüzyılda Tur-1 Sina manastırı, in XIV. Türk tarih kongresi, 9-13 Eylül 2002 Ankara, ii, part 2, Ankara 2005, 1403-1411.

Açık, T., Dede Cöngî'nin Siyâsetü'ş-şer'iyye'sinin Mehmed Sebzî Efendi tercümesi, in Littera Turca:Journal of Turkish language and literature 2 (2016), 1-24.

Akgündüz, A., Dede Cöngî, in TDVIA, ix, 76-77.

Alexander, J.C., The lord giveth and the lord taketh away: Athos and the confiscation affair of 1568-1569, Mount Athos in the 14th-16th centuries, in Athonika Symmeikta 4 (1997), 168-169.

Andrews, W. and M. Kalpakl, The age of beloveds: Love and the beloved in early-modern Ottoman and European culture and society, Durham and London 2005.

Anjum, O., Politics, law and community in Islamic thought:The Taymiyyan moment, Cambridge 2012.

Anthony, S.W., The caliph and the heretic: Ibn Saba' and the origins of Shi'ism (IHC 91), Leiden 2012. 
Atiya, A.S., The Arabic manuscripts of Mount Sinai, Baltimore 1955.

Atçl, A., The Safavid threat and juristic authority in the Ottoman Empire during the sixteenth century, in IJMES 49 (2017), 295-314.

Ayalon, D., The great Yāsa of Chinggis Khān: A reexamination, in SI 33 (1971): 97-140; 34 (1971): 151-180; 36 (1972), 113-158; 38 (1973), 107-156.

Ayalon, D., The Mamlūk military aristocracy: A non-hereditary nobility, in JSAI 10 (1987), 209-210.

Aykan, Y., Rendre le justice à Amid: Procédures, acteurs et doctrines dans le contexte ottoman du XVIII ${ }^{\text {ème }}$ siècle (OEH 6o), Leiden 2016.

Aykan, Y., A legal concept in motion: The "spreader of corruption" (sā' $\bar{\imath}$ bil-fesād) from Qarakhanid to Ottoman jurisprudence, in Islamic law and society 26 (2019), 252-271. Ayoub, S. "The sulțān says": State authority in the late Hanafī tradition, in Islamic law and society 23 (2016), 239-278.

Ayoub, S.A., Law, empire, and the sultan: Ottoman imperial authority and late Hanafi jurisprudence, Oxford 2020.

Baer, M.D., Honored by the glory of Islam: Conversion and conquest in the Ottoman Empire, Oxford 2008.

Baldwin, J.E., Islamic law and empire in Ottoman Cairo, Edinburgh 2017.

Barkan, Ö.L., XV ve XVI'ıncı asırlarda Osmanlı Imparatorluğunda zirai ekonominin hukuki ve mali esasları, Istanbul 1943.

Barkan, Ö.L., Kanun-nâme, in iA, vi, 185-196.

Beaudoen, L.A., Mirrors of the world: Alexander romances and the fifteenth-century Ottoman sultanate, PhD diss., University of California, Los Angeles 2017.

Belhaj, A., Law and order according to Ibn Taymiyya and Ibn Qayyim al-Jawziyya: A reexamination of siyāsa shar iyya, in B. Krawietz and G. Tamer (eds.), Islamic theology, philosophy and law: Debating Ibn Taymiyya and Ibn Qayyim al-Jawziyya, in collaboration with Alina Kokoschka (SG KIO 27), Berlin and Boston 2013, 400-421.

Bori, C., One or two versions of al-Siyāsa al-Shar 'iyya? And what do they tell us? in ASK working papers 26 (2016), 1-27.

Bori, C., Ibn Taymiyya (14th to 17 th century): Transregional spaces of reading and reception, in $M W 108$ (2018), Special issue: C. Bori (ed.), Ibn Taymiyya: Receptions (14th to $17^{\text {th }}$ century), 87-123.

Bosworth, C.E.I.R. Netton and F.E. Vogel, Siyāsa, in $E I^{2}$, ix, 693-696.

Burak, G., Between the kānūn of Qāytbāy and Ottoman yasaq: A note on the Ottoman's dynastic law, in JIS 26 (2015), 1-23.

Burak, G., Faith, law and empire in the Ottoman "age of confessionalization" (fifteenthseventeenth centuries): The case of "renewal of faith," in Mediterranean historical review 28 (2013), 1-23.

Burak, G., The second formation of Islamic law: The Hanafi legal school in the Ottoman Empire, Cambridge 2015. 
Burak, G., The second formation of Islamic law: The post-Mongol context of the Ottoman adoption of a school of law, Comparative studies in society and history 55 (2013), 579-6o2.

Buzov, S., The Lawgiver and his lawmakers: The role of legal discourse in the change of imperial culture, $\mathrm{PhD}$ diss., University of Chicago 2005.

Büyükkeçeci, B., Kadızâde İlmî Efendi’nin “İtmâmü'l-merâm min nazmi'l-kelam” adlı eserinin tahlil, çeviri ve değerlendirilmesi, MA thesis, Erciyes Üniversitesi 2005.

Cohen, M.R., What was the pact of 'Umar? A literary-historical study, in JSAI 23 (1999), 100-157.

Cook, M. Commanding right and forbidding wrong in Islamic thought, Cambridge 2004.

Coşgel M. et al., Crime and punishment in Ottoman times: Corruption and fines, in Journal of interdisciplinary history 43 (2013), 353-376.

Currie, J.M.D., Kadızadeli Ottoman scholarship, Muhammad ibn Abd al-Wahhāb, and the rise of the Saudi state, in JIS 26 (2015), 1-25.

Çavuşoğlu, S., The Käạdizādeli movement: An attempt of şerîat-minded reform in the Ottoman Empire, PhD diss., Princeton University 1990.

Çıpa, E., The making of Selim: Succession, legitimacy, and memory in the early modern Ottoman world, Bloomington 2017.

Darling, L.T., A history of social justice and political power in the Middle East: The circle of justice from Mesopotamia to globalization, Abingdon 2013.

Deniz, S., Kadızâde Mehmed İlmî'nin Sultan IV. Murad için yazdığı manzum duânâmesi, in Divan edebiyatı araştırmaları dergisi 1 (2008), 9-40.

Dressler, M., Inventing orthodoxy: Competing claims for authority and legitimacy in the Ottoman Safavid conflict, in H.T. Karateke and M. Reinkowski (eds.), Legitimizing the order: The Ottoman rhetoric of state power ( $\mathrm{OEH} 34$ ), Leiden and Boston 2005, 151-176.

Eberhard, E. Osmanische Polemik gegen die Safawiden im 16. Jahrhundert nach arabischen Handschriften, Freiburg im Breisgau, 1970.

Erel, Z.G., Dede Cöngî's Risâletü Siyâsetü'ş-şer'iyye: A context analysis through its translations in the sixteenth and nineteenth centuries, MA thesis, Bilkent University 2012.

Ergene, B., Local court, provincial society and justice in the Ottoman Empire: Legal practice and dispute resolution in Çankırı and Kastamonu (1652-1744) (SILS 17), Leiden 2003 .

Ergene, B., Qanun and sharia, in R. Peters and P.J. Bearman (eds.), The Ashgate research companion to Islamic Law, London and New York 2014.

Erten, M., Tercüme-i siyâsetnâme'nin tahlîli ve değerlendirmesi, PhD diss., Ankara Üniversitesi 2011.

Evstatiev, S., The Qādīzādeli movement and the spread of Islamic revivalism in the seventeenth- and eighteenth-century Ottoman Empire: Preliminary notes, in $c A S$ working papers series 5 (2013), 3-34. 
Evstatiev, S., The Qādīzādeli movement and the revival of takfír in the Ottoman age, in C. Adang et al. (eds.), Accusations of unbelief in Islam: Diachronic perspectives on takfir (IHC 123) Leiden and Boston 2016, 213-243.

Ferguson, H., The proper order of things: Language, power and law in Ottoman administrative discourses, Palo Alto 2018.

Fitzgerald, T.J., Murder in Aleppo: Ottoman conquest and the struggle for justice in the early sixteenth century, in JIS 27 (2016), 176-215.

Fleischer, C.H., The Lawgiver as Messiah: Messianic dimensions in the development of Ottoman imperial ideology, in G. Veinstein (ed.), Soliman le Magnifique et son temps, Paris 1992, 159-179.

Flemming, B., Political genealogies in the sixteenth century, in Jos 7-8 (1988), 123-137.

Fotić, A., The official explanations for the confiscation and sale of monasteries (churches) and their estates at the time of Selim II, in Turcica 26 (1994), 33-54.

Furat, A.H., Selefîliğin Osmanlıya etkisi bağlamında kullanılan bir argüman: İbn Teymiyye'nin es-Siyâsetü’ş-şer'iyye adlı eserinin Osmanlı dünyasında xvi. ve xvii. asırlardaki tercümeleri, in Marife dergisi 3 (2009), 215-226.

Gel, M., XVI. yüzyılın ilk yarısında Osmanlı toplumunun dinî meselelerine muhalif bir yaklaşım: Şeyhülislam Çivizade Muhyiddin Mehmed Efendi ve fikirleri üzerine bir inceleme, PhD diss., Gazi Üniversitesi 2010.

Greene, M., A shared world: Christians and Muslims in the early modern Mediterranean, Princeton 2000.

Greene, M., An Islamic experiment? Ottoman land policy on Crete, in Mediterranean historical review 11, 1 (1996), 6o-78.

Greene, M., The Edinburgh history of the Greeks, 1453-1768: The Ottoman Empire, Edinburgh 2015 .

Gril, D. Ésotérisme contre hérésie: Abd al-Rahman al-Bistami, un representant de la science des lettres à Bursa dans la premiere moitié du xve siècle, in G. Veinstein (ed.), Syncrétismes et hérésies dans l'orient seldjoukide et ottoman (xive-xviiie siècle), 183-195.

Hagen, G., Translations and translators in a multilingual society: A case study of Persian-Ottoman translations, late fifteenth to early seventeenth century, in Eurasian studies 2 (2003), 95-134.

Hassan, M., Modern interpretations and misinterpretations of a medieval scholar: Apprehending the political thought of Ibn Taymiyya, in Rapoport and Ahmed (eds.), Ibn Taymiyya and his times, $338-366$.

Hassan, M., Longing for the lost caliphate: A transregional history, Princeton and Oxford 2016.

Heyd, U., Studies in old Ottoman criminal law, Oxford 1973.

Heyd, U., Kānūn and sharī‘a in old Ottoman criminal justice, in Proceedings of the Israel academy of sciences and humanities 3 (1967), 1-18. 
Holt, P.M., The position and power of the Mamlūk sultan, in BSOAS 38 (1975), 237-249. Ibrahim, A.F., Pragmatism in Islamic law: A social and intellectual history, Syracuse 2015. İhsanoğlu, E. (ed.), Osmanlı askerlik literatürü tarihi/History of military art and science literature during the Ottoman period, 2 vols., Istanbul 2004.

Imber, C., Ebu's-su'ud: The Islamic legal tradition, Palo Alto 1997.

Imber, C., The persecution of the Ottoman Shīites according to the Mühimme defterleri, 1565-1585, in Der Islam $5^{6}$ (1979), 245-273.

İnalcık, H., Islamization of Ottoman laws on land and land tax, in C. Fragner and K. Schwarz (eds.), Festgabe an Josef Matuz: Osmanistik-Turkologie-Diplomatik, Berlin 1992, 101-118.

İnalcık, H., Kānūn, iii. Financial and public administration, in $E I^{2}$, iv, $55^{8-562 .}$

İnalcık, H., Kānūnnāme, in $E I^{2}$, iv, 562-566.

İpşirli, M., Minkārizâde Yahyâ Efendi, in TDVIA, xxx, 114-115.

Ivanyi, K., Virtue, piety and the law: A study of Birgivī Meḥmed Efendi's al-Ṭaìqa alMuhammadiyya, PhD diss., Princeton University 2012.

Johansen, B., Signs as evidence: The doctrine of Ibn Taymiyya (1263-1328) and Ibn Qayyim al-Jawziyya (d. 1351) on proof, in Islamic law and society 9 (2002), 168-193.

Johansen, B., The Islamic law on land tax and rent: The peasants'loss of property rights as interpreted in the Hanafite legal literature of the Mamluk and Ottoman periods, London, New York, Sydney 1988.

Karaca, S., Kadızâde Mehmed Efendi, Manzume-i akâid (inceleme-tenkitli metin-sözlük-dizin), MA thesis, Recep Tayyip Erdoğan Üniversitesi 2012.

Karaman, A., Trablusî, Alâaddin, in TDVIA, xli, 291-292.

Karamustafa, A.T., Saraydan tasavvuf manzaraları: Atûfînnin Defter-i Kütüb'ündeki tasavvufî eserlerin bir tasavvuf tarihçisine düşündürdükleri, in E. Alkan and O.S. Arı (eds.), Osmanlida ilm-i tasavvuf, Istanbul 2018, 49-58.

Karatay, F.E., Topkapı Sarayı Müzesi Kütüphanesi Arapça yazmalar, Istanbul 1966.

Kastritsis, D. The Alexander romance and the rise of the Ottoman Empire, in A.C.S. Peacock and S.N. Ylldız (eds.), Islamic literature and intellectual life in fourteenth-and fifteenth-century Anatolia (ITs 34), Würzburg 2016, 243-283.

Katz, M.H., The "corruption of the times" and the mutability of the shari'a, in Cardozo law review 28 (2006), 171-185.

Kaylı, A., A critical study of Birgivi Mehmed Efendi's (d. H. 981/1573) works and their dissemination in manuscript form, MA thesis, Boğaziçi University 2010.

Kermeli, E., Caught in between faith and cash: The Ottoman land system of Crete, $1645^{-}$ 1670, in A. Anastasopoulos (ed.), The eastern Mediterranean under Ottoman rule: Crete, 1645-1840, Rethymno 2008, 17-48.

Kermeli, E., Central administration versus provincial arbitrary governance: Patmos and Mount Athos monasteries in the 16th century, in Byzantine and modern Greek studies $32(2008), 189-202$. 
Kermeli, E., Ebū's-su'ūd's definitions of church vakfs: Theory and practice in Ottoman law, in R. Gleave and E. Kermeli (eds.), Islamic law: Theory and practice, London and New York 1997, 141-156.

Khadduri, M., Mașlaha, in $E I^{2}$, vi, $738-740$.

Khoury, D.R., Administrative practice between religious law (shari'a) and state law (kanun) on the eastern frontiers of the Ottoman Empire, in Journal of early modern history 5/4 (2001), 182-212.

Kolovos, E., Beyond "classical" defterology: A preliminary assessment of the tahrir registers of 1670/71 concerning Crete and the Aegean islands, in E. Kolovos et al. (ed.), The Ottoman Empire, the Balkans, the Greek lands: Toward a social and economic history: Studies in honor ofJohn C. Alexander, Istanbul 2007, 201-235.

Kolovos, E., Christian vakıfs of monasteries in the Ottoman Greek lands from the fourteenth to eighteenth centuries, in S.M. Saliba (ed.), Les fondations pieuses waqfs chez les chretiéns et les juifs du Moyen Âge à nos jours, Paris 2016, 103-127.

Köksal, A.C., Fıkıh ve siyaset: Osmanlılarda siyâset-i şer'iyye, Istanbul 2016.

Krstić, T., Contested conversions to Islam: Narratives of religious change in the early modern Ottoman Empire, Cambridge 2011.

Krstić, T., Illuminated by the light of Islam and the glory of the Ottoman sultanate: Self-narratives of conversion to Islam in the age of confessionalization, Comparative studies in society and history $5^{1}$ (2009), 35-63.

Krstić, T., From shahāda to 'aqìda: Conversion to Islam, catechisation and Sunnitisation in A.C.S. Peacock (ed.), Islamisation: Comparative perspectives from history, Edinburgh 2017, 296-314.

Krstić, T., Of translation and empire: Sixteenth-century Ottoman imperial interpreters as Renaissance go-betweens, in C. Woodhead (ed.), The Ottoman world, Abingdon 2012, 130-142.

Krstić, T., State and religion, "Sunnitisation" and "confessionalism" in Süleyman's time, in P. Fodor (ed.), The battle for Central Europe: The siege of Szigetvár and the death of Süleyman the Magnificent and Miklos Zrinyi (1566), Leiden, Boston, Budapest 2019, 65-91.

Laoust, H., Essai sur les doctrines sociales et politiques de Taḳi-d-dīn Aḥmad b. Taimīya, Cairo 1939 .

Laoust, H., Ibn Taymiyya, in $E I^{2}$, iii, 951-955.

Laoust, H., Le traité du droit d'Ibn Taimīya, Beirut 1948.

Lekesiz, M.H., XVı. Yüzyıl Osmanlı düzenindeki değişimin tasfiyeci (püritanist) bir eleştirisi: Birgivi Mehmet Efendi ve fikirleri, PhD diss., Hacettepe Üniversitesi 2007. Lev, Y., Symbiotic relations: ulama and the Mamluk sultan, in MSR 13 (2009), 1-26. Levanoni, A., The Mamluk conception of the sultanate, in IJMES 26 (1994), 373-392. Mandaville, J.E., Usurious piety: The cash waqf controversy in the Ottoman Empire, in IJMES 10 (1979), 280-308. 
Martı, H., Birgivî Mehmed Efendi, Ankara 2008.

Massud, M.K., The doctrine of siyāsa in Islamic law, in Recht van de Islam 18 (2001), 1-29. al-Matroudi, A.H.I., The Hanbali school of law: Conflict or conciliation, London 2006.

Melchert, C., The relation of Ibn Taymiyya and Ibn Qayyim al-Jawziyya to the Hanbalī school of law, in B. Krawietz and G. Tamer (eds), Islamic theology, philosophy and law: Debating Ibn Taymiyya and Ibn Qayyim al-Jawziyya, in collaboration with Alina Kokoschka (SGKIO 27), Berlin and Boston 2013, 146-161.

Meshal, R., Antagonistic shari`as and the construction of orthodoxy in sixteenth-century Ottoman Cairo, in JIS 21 (2010), 183-212.

Michot, Y., Introduction, in A.R. al-Aqhịisārī, An Ottoman manifesto against smoking: An introduction, editio princeps and translation, ed. Y. Michot, Leicestershire 2010.

Midilli, M., Dede Cöngi'nin Siyâsetü'ş-şer'iyye'si Osmanlı ceza kanunlarının hukukî temellendirmesi midir?, in Osmanlida ilm-i fıkıh: Âlimler, eserler, meseleler, İstanbul 2017.

Moritz, B., Beiträge zur Geschichte des Sinaiklosters im Mittelalter nach arabischen Quellen, Berlin 1918.

Morrow, J.A., The covenants of the prophet Muhammad with the Christians of the world, New York 2013.

Mundy, M. and R.S. Smith, Governing property, making the modern state: Law, administration, and production in Ottoman Syria, London 2007.

Muslu, C. Yüksel, The Ottomans and the Mamluks: Imperial diplomacy and warfare in the Islamic world, London and New York 2014.

Necipoğlu, G., The age of Sinan: Architectural culture in the Ottoman Empire, Princeton 2005 .

Necipoğlu, G., Süleyman the Magnificent and the representation of power in the Ottoman-Habsburg-Papal rivalry, in The art bulletin 71 (1989), 401-427.

Necipoğlu, G. et al. (ed.), Treasures of the palace: An inventory of the Ottoman palace library (1502/3-1503/4), 2 vols., Leiden and Boston 2019.

Nielsen, J.S., Secular justice in an Islamic state: Mazālim under the Bahrī Mamlūks, 662/1264-789/1387, Leiden 1985.

Nizri, M., Ottoman high politics and the ulema households, New York 2014.

Ocak, A.Y. XVI I. yüzyılda Osmanlı İmparatorluğu'nda dinde tasfiye (püritanizm) teşebbüslerine bir bakış: Kadızadeliler hareketi, in Türk kültürü araştırmaları 1-2 (1983), 208-225.

Ökten, E., Scholars and mobility: A preliminary assessment from the perspective of alShaqāyiq al-Numāniyya, in Jos 41 (2013), 55-70.

Özcan, A., Hüsrev Paşa, Deli, in TDVIA, xix, 40-41.

Özer, A., İslam hukuk literatüründe ta'zîr risaleleri ve şeyhülislam Muhyiddin Mehmed bin İlyas Çivizâde'nin Risale müteallika bi't-teâzir adlı eseri, MA thesis, Marmara Üniversitesi 2000. 
Öznurhan, H., Abbâsî, Abdürrrahîm, in TDViA, ek-1, 5-6.

Öztürk, N., Islamic orthodoxy among the Ottomans in the seventeenth century with special reference to the Qādīi-zāde movement, PhD diss., University of Edinburgh 1981.

Peirce, L., Morality tales: Law and gender in the Ottoman court of Aintab, Berkeley, Los Angeles, London 2003.

Peters, R., Crime and punishment in Islamic law: Theory and practice from the sixteenth to the twenty-first century, Cambridge 2006.

Peters, R., 'What does it mean to be an official madhhab?': Hanafism and the Ottoman Empire, in P. Bierman et al. (eds.), in The Islamic school of law: Evolution, devolution and progress, Cambridge, MA 2005, 147-158.

Pfeifer, H., Encounter after the conquest: Literary salons in 16th-century Ottoman Damascus, in IJMES 47 (2015), 219-239.

Radtke, B., Birgiwīs Ṭarīqa Muḥammadiyya: Einige Bemerkungen und Überlegungen, in Journal of Turkish studies 26 (2002), 159-174.

Rapoport, Y., Royal justice and religious law: Siyāsah and shari'ah under the Mamluks, in MSR 16 (2012), 71-102.

Rapoport, Y., Legal diversity in the age of taqlìd: The four chief qādīis under the Mamluks, Islamic law and society 10 (2003), 210-228.

Reinhart, A.K., When women went to mosques: al-Aydini on the duration of assessments, in M.K. Masud et al. (eds.), Islamic legal interpretation: Muftis and their fatwas, Cambridge, MA and London 1996, 116-128.

Repp, R., Qānūn and sharīa in the Ottoman context, in A. al-Azmeh (ed.), Islamic law: Social and historical contexts, London 1988, 124-145.

Richards, D.S., Mamlūk amirs and their families and households, in T. Philipp and U. Haarmann (eds.), The Mamlūks in Egyptian politics and society, Cambridge 1998, 32-54.

el-Rouayheb, Kh., Before homosexuality in the Arab-Islamic world, 1500-1800, Chicago and London 2005.

el-Rouayheb, Kh., From Ibn Ḥajar al-Haytamī (d. 1566) to Khayr al-Dīn al-Ālūsī (d. 1899): Changing views of Ibn Taymiyya amongst Sunni Islamic scholars, in Y. Rapoport and S. Ahmed (eds.) Ibn Taymiyya and his times, Oxford 2010, 269-318.

Sariyannis, M., A history of Ottoman political thought up to the early nineteenth century, with a chapter by E.E. Tuşalp Atiyas (HO 125), Leiden and Boston 2019.

Sariyannis, M., Notes on the Ottoman poll-tax reforms of the late seventeenth century: The case of Crete, in JESHO 54 (2011), 39-61.

Sariyannis, M., The Kadıadeli movement as a social and political phenomenon: The rise of a "mercantile ethic"? in A. Anastasopoulos (ed.), Political initiatives from the bottom-up in the Ottoman Empire (Halcyon days in Crete VII. A symposium held in Rethymno, 9-11 January 20o9), Rethymno 2012, 263-289. 
Semerdjian, E., "Off the straight path": Illicit sex, law, and community in Ottoman Aleppo, Syracuse 2008.

Sezer, Y., The architecture of bibliophilia: Eighteenth-century Ottoman libraries, PhD diss., Massachusetts Institute of Technology 2016.

Shafir, N., Moral revolutions: The politics of piety in the Ottoman Empire reimagined, in Comparative studies in society and history 61 (2019), 595-623.

Sheikh, M., Ottoman puritanism and its discontents: Aḥmad al-Rumī al-Aqhịsārī and the Qādizādelis, Oxford 2016.

Sheikh, M., Taymiyyan influences in an Ottoman-Hanafĩ milieu: The case of Aḥmad al-Rumī al-Aqhịsārī, in The royal Asiatic society 3 (2014), 1-20.

Sheikh, M., Taymiyyan tașawwuf meets Ottoman orthodoxy: Reformed Sufism in the thought of Aḥmad al-Rumī al-Aqhịsāāī, in $M W 108$ (2018), Special issue: C. Bori (ed.), Ibn Taymiyya: Receptions (14th to 17th century), 186-206.

Stilt, K., Islamic law in action: Authority, discretion, and everyday experiences in Mamluk Egypt, Oxford 2011.

Şahin, İ.K., Empire and power in the reign of Süleyman: Narrating the sixteenth-century Ottoman world, New York and Cambridge 2013.

Şen, T.A., The dream of a 17th-century Ottoman intellectual: Veysi and his Habname, MA thesis, Sabancı University 2008.

Şimşek, M., Les controverses sur la Bid'a en Turquie (de Selim I à Mehmed IV), PhD diss., Université de Paris-Sorbonne 1977.

Taşkömür, H., Books on Islamic jurisprudence, schools of law, and biographies of imams from the Hanafi school, in Necipoğlu et al. (ed.), Treasures of the palace, 389422.

Terzioğlu, D., Bid'at, custom and the mutability of shar ' $\overline{~ j u d g m e n t s: ~ T h e ~ d e b a t e ~ o n ~ t h e ~}$ congregational performance of supererogatory prayers in the seventeenth-century Ottoman Empire, in A. Somel and S. Kenan (eds.), Dimensions of transformation in the Ottoman world: Essays in honor of Metin Kunt, Leiden, forthcoming.

Terzioğlu, D., Bir tercüme ve bir intihal vakası: Ya da İbn Teymiyye'nin Siyasetü’şşer'iyye'sini Osmanlıcaya kim(ler) nasıl aktardı?, in Journal of Turkish studies 31 (2007), 247-275.

Terzioğlu, D., How to conceptualize Ottoman Sunnitization: A historiographical discussion, in Turcica 44 (2012-2013), 301-338.

Terzioğlu, D., Sunna-minded Sufi preachers in service of the Ottoman state: The nașihatnāme of Hasan addressed to Murad IV, in Archivum Ottomanicum 27 (2010), 241-312.

Terzioğlu, D., Where 'ilm-i ḥāl meets catechism: Islamic manuals of religious instruction in the Ottoman Empire in the age of confessionalization, in Past and present 220 (2013), 79-114.

Tezcan, B., A canon of disenchantment: Birgivi, Rumi and Kadızade, in B. Tezcan, A Gift 
for the Turks: Studies on Islam and its Early Modern Transformation in the Ottoman Empire, Istanbul, forthcoming in 2020.

Tezcan, B., Ethics as a domain to discuss the political: Kınalızâde Ali Efendi's Ahlâk$\iota$ Alât, in A. Çaksu (ed.), International congress on learning and education in the Ottoman world, Istanbul 12-15 April 1999, Istanbul 2001, 109-120.

Tezcan, B., The 'Kânûnnâme of Mehmed II': A different perspective, in K. Çiçek (ed.), The great Ottoman Turkish civilization, iii, Ankara 200o, 657-665.

Tezcan, B., The portrait of the preacher as a young man: Two autobiographical letters by Kadızade Mehmed from the early seventeenth century, in M. Sariyannis (ed.), Political thought and practice in the Ottoman Empire (Halcyon days in Crete IX, A symposium held in Rethymno 9-11 January 2015), Rethymno 2019, 187-250.

Tezcan, B., The second Ottoman Empire: Political and social transformation in the early modern world, Cambridge 2010.

Thys-Şenocak, L., The Yeni Valide complex at Eminönü, in Muqarnas 15 (1998), 58-70.

Al-Tikriti, N., Kalam in the service of the state: Apostasy and the defining of Ottoman Islamic identity, in H.T. Karateke and M. Reinkowski (eds.), Legitimizing the order: The Ottoman rhetoric of state power (OEH 34), Leiden and Boston 2005, 131-149.

Tuğ, B., Politics of honor in Ottoman Anatolia: Sexual violence and socio-legal surveillance in the eighteenth century ( $\mathrm{OEH} 62$ ), Leiden and Boston 2017.

Turan, E., The sultan's favorite: İbrahim Pasha and the making of the Ottoman universal sovereignty in the reign of Sultan Süleyman I (1516-1526), PhD diss., University of Chicago 2007.

Tuşalp Atiyas, E.E., The "sunna-minded" trend, in M. Sariyannis, A history of Ottoman political thought, 233-278.

Ürekli, B., Dördüncü Murad devrine dâir Kadı-zâde'nin bir manzûmesi, in Selçuk Üniversitesifen-edebiyat fakültesi dergisi 11 (1997), 277-300.

Üstün, İ.S., Heresy and legitimacy in the Ottoman Empire in the sixteenth century, PhD diss., University of Manchester, 1991.

Veinstein, G., Le législateur ottoman face à l'insularité: L'enseignement des Kânûnnâme, in N. Vatin and G. Veinstein (ed.), Insularités ottomanes, Paris 2004, 91-110.

Veinstein, G., Les règlements fiscaux ottomans de Crète, in A. Anastasopoulos (ed.), The Eastern Mediterranean under Ottoman rule: Crete, 1645-1840, Rethymno 2008, 3-16.

Veinstein, G., On the çiftlik debate, in Ç. Keyder and F. Tabak (eds.), Landholding and commercial agriculture in the Middle East, Albany 1991.

Welle, J., The status of monks in Egypt under early Mamlūk rule: The case of Ibn Taymiyya (with an annotated translation of Ibn Taymiyya's fatwā on the status of monks), in Logos: A journal of eastern Christian studies 55 (2014), 41-67.

Winter, M., Society and religion in early Ottoman Egypt: Studies in the writings of 'Abd al-Wahhāb al-Sha'rānī, New Brunswick 2017.

Winter, S., The Shiites of Lebanon under Ottoman rule, 1516-1788, Cambridge 2010. 
Yıldız, K., 166o İstanbul yangını ve etkileri: Vakıflar, toplum ve ekonomi, Ankara 2017.

Yılmaz, H., Caliphate redefined: The mystical turn in Ottoman political thought, Princeton 2018.

Yosef, K., Mamluks and their relatives in the period of the Mamluk Sultanate $\left(125^{\circ-}\right.$ 1517), in MSR 16 (2012), 55-69.

Yürekli, Z., A building between the public and private realms of the Ottoman ruling elite: The Sufi convent of Sokollu Mehmed Paşa in Istanbul, in Muqarnas 20 (2003), 159-185.

Zarinebaf, F., Crime and punishment in Istanbul, 1700-1800, Berkeley, Los Angeles, London 2010.

Zilfi, M., The Kadızadelis: Discordant revivalism in seventeenth-century Istanbul, in JNES 4 (1986), 251-271.

Zilfi, M., The politics of piety: The Ottoman ulema in the postclassical age (1600-180o), Minneapolis 1988.

Zilfi, M., Women and slavery in the late Ottoman Empire, Cambridge 2010. 